\title{
When all seemed lost. A social network analysis of the waste-related environmental movement in Campania, Italy
}

\author{
Pasquale Marcello Falcone ${ }^{a, *}$, Giacomo D’Alisa ${ }^{b}$, Anna Rita Germani ${ }^{c}$, Piergiuseppe Morone ${ }^{a}$ \\ ${ }^{a}$ Department of Law and Economics, Unitelma Sapienza - University of Rome, V Regina Elena, 291, 00161, Roma, Italy \\ ${ }^{\mathrm{b}}$ Centre for Social Studies - University of Coimbra, Colégio de S. Jerónimo, Largo D. Dinis Apartado 3087, 3000-995, Coimbra, Portugal \\ ${ }^{\mathrm{c}}$ Department of Law and Economic Studies, University of Rome "La Sapienza", P.le Aldo Moro, 5, 00185, Rome, Italy
}

\section{A R T I C L E I N F O}

\section{Keywords:}

Environmental justice

Grassroot environmentalism

Waste management

Social network analysis

\begin{abstract}
A B S T R A C T
The Italian region of Campania and its capital Naples have epitomized waste management failure in Europe since 2008 when international media covered extensively the waste crisis occurring there. In response to the crisis, the Italian national government took an authoritarian turn in waste policies and criminalized citizens' grievances and mobilizations against waste-facility siting in Campania. The state authorities' intervention gained popular consent and obscured the multifaceted and unjust geographies of waste management in the region. It was a serious blow for the waste-related justice movement in Campania. However, just when waste management seemed under control the movement re-emerged stronger and more effective than it had been prior to the 2008 crisis. Activists created a new counter narrative and liberated themselves from the constraints imposed by the repressive measures of the national government. They built a new frame around the unhealthy space, whose expansion, they maintained, was caused by the waste-related contamination. Yet the strength of the movement and its transformation following 2008 can only be fully understood when the structural property and the components of the EJ activists' networks are also considered. We apply a Social Network Analysis to show how an effective environmental justice movement requires a cohesive and robust network as well as a comprehensive narrative. The waste-related movement in Campania went from being an archipelago of isolated clusters of organizations with a plural but fragmented claims (before 2008), to a tightly interconnected network supporting a unified political platform (after 2008). We link together the reframing of the movement around health issues with the reconfiguration of activist networks. We use the Campania case to show how environmental justice movements might overcome repression and criminalization and progress toward social justice and ecologically sound transformations.
\end{abstract}

\section{Introduction}

For fifteen years since 1994, the Italian government has imposed a state of emergency around the waste crisis in the Southern Italian region of Campania, whose capital is Naples. Ad hoc commissioners were appointed to solve the waste crisis because Campania's regional government had been unable to approve a management plan and build the needed infrastructure. In 2009, as the waste crisis worsened, the Italian Prime Minister (PM hereafter) decided to take the crisis head on. He ordered the national army to clean up Naples' streets where tons of waste had piled up. He also called a series of Cabinet Ministers' meetings in Naples to show the crisis was a national priority. With these interventions, the PM gained the consent of the Italian political spectrum and most of its citizens. The government's takeover of waste management in Campania was perceived as a sort of political miracle (D'Alisa \& Armiero, 2013). After the clean-up, the PM issued a decree (Decree $n$. 90) and declared that the state of emergency was over, and planning activities would be returned to the regional government. The decree made demonstration in the vicinity of waste facilities a penal felony. The aim was to stop protests and riots, such as the ones that occurred in Pianura, on the outskirts of Naples, throughout 2008 (De Biase, 2015). The result of the clause was that citizens' claims and waste-related

\footnotetext{
* Corresponding author.

E-mail addresses: pasquale.falcone@unitelmasapienza.it (P.M. Falcone), giacomodalisa@ces.uc.pt (G. D’Alisa), annarita.germani@uniroma1.it (A.R. Germani), piergiuseppe.morone@unitelmasapienza.it (P. Morone).
} 
activists, who the PM charged a "trouble-maker minority", ${ }^{1}$ were criminalized.

For decades, activists in Campania had been denouncing the unsafe use of existing regional landfills, the illegal practice of burying and burning industrial waste around the countryside, the lack of control over illegal waste trafficking, the increasing contamination of both soil and water, and the absence of citizen participation in the decision making process in designing the waste-management plan (Armiero \& D'Alisa, 2013; D'Alisa, Burgalassi, Healy, \& Walter, 2010). Since 2008, the Campania region had become the icon of waste mismanagement in Europe and a case of environmental injustice (Armiero \& D'Alisa, 2012).

The media increasingly discredited the claims and activities of the heterogeneous group of activists. It portrayed mobilized citizens as political puppets who rejected any solution the central government proposed (Pasotti, 2010) or as working for the camorra (the Neapolitan mafia), whose interest in waste trafficking was common knowledge (Fisher, 2007; The Economist, 2008). However, these very partial narratives (Armiero \& D'Alisa, 2013; D'Alisa, Armiero, \& De Rosa, 2014) alongside the authoritative drift caused by Decree n. 90 did not discourage all the activism. The activists slowly reorganized, creating new links with new grassroots organizations that were emerging due to the impact of waste-related contamination. As the geography of the movement changed, its organizational capacity scaled up; the movement expanded its scope and launched an innovative project of re-territorialization (De Rosa, 2018).

In 2010 and 2011, most policymakers could not see the mounting strength of the waste-related movement; the still existing skirmishes were considered a leftover from the past. Thus, politicians looked with astonishment at the massive mobilization of the 16th of November 2, $013^{2}$ in Naples' city center. The streets were now clean and waste management had normalized; yet more than 100.000 people marched. The slogan that unified these people was: Stop Biocide. A health issue was the binding matter of contention that gave life to the new movement; contamination caused by decades of waste mismanagement gradually emerged in flesh and bone and the people's ill bodies became politicized (Iengo \& Armiero, 2017). For the populace, the increasing morbidity and mortality from cancer in the region was caused by both the illegal trafficking and disposal of industrial waste and the legal mismanagement of urban waste.

Recent studies point to the important achievements of these new movement configurations. These include: the ability to force the national government to recognize the burning of waste as an environmental crime (D'Alisa, Germani, Falcone, \& Morone, 2017); the capacity to envision projects of territorialization that challenge violent appropriation and the state of emergency (De Rosa, 2018); and, the move of activists from "simply" complaining of waste mismanagement and illegal waste traffic's systematic contamination to the enactment of "commoning" practices to produce wine and organic food on land seized from camorra families (Armiero \& Sgueglia, 2019).

However, in our view, what is still important to analyze is how, in a moment of strong repression, the waste-related environmental movement in Campania was able to re-structure its organization and rearticulate its narrative. Filling this gap is particularly important because this reconfiguration, which guaranteed the movement more strength and effectiveness, happened when the national government's repressive measures favoring corporate interests should have engendered the demise of such EJ movements. We apply a Social Network

\footnotetext{
${ }^{1}$ Berlusconi used these words for speaking about waste-related activists in Campania in one of his first press conference as Prime minister (Naples, May 21, 2008).

${ }^{2}$ See: https://www.systemfailurewebzine.com/centomila-persone-corteo-na poli-un-vero-fiume-piena/; and https://napoli.repubblica.it/cronaca/2013/ 11/16/news/don_patriciello_questo_corteo_un_fiume_in_piena_decine_di_mi gliaia_in_marcia_sotto_la_pioggia-71164509/.
}

Analysis (SNA hereafter) to the Campania case. We sketch the evolution of grassroots activist involvement, over time, investigating their networks of relations both before and after the occurrence of two crucial socio-political events in 2008: (i) the accumulation of a huge amount of waste in the streets of Naples, and the consequent worldwide media coverage of this disastrous waste management; (ii) the issue of the Decree 90/2008 (converted into Law 123/2008), which called for the construction of ten landfills and four incinerators in Campania and criminalized any activity organized in the proximity of waste facilities.

Studying the evolution of the Campania EJ movement and highlighting the structural properties and the composition of its networks both before and after the turning point (the year 2008), we aim to show how the grassroots movement has resisted its criminalization and gained strength in a moment of political threat that tried to weaken it. In addressing such issues, we inform more general concerns of EJ scholars and activists, that is, how EJ organizations can learn from each other and further their own claims and struggles in a moment when everything seems lost.

In the next section, we delineate some of the current cutting-edge and interdisciplinary interests of EJ literature. We then show the contribution of our analysis to this scholarship. In section 3, we detail the employed SNA methodology, the collection and processing of the data that has allowed us to unveil the articulation and the composition of the different networks of the Campania movement. In section 4, we describe our main findings and corroborate our hypothesis that a diversification of the network, the intensification of the link between the actors of the struggle, and a unified narrative centered around health injustice caused by the waste-related contamination is key to understanding the improved strength of the movement. Finally, we conclude by delineating the main findings and showing the future potential of EJ scholarship that chooses to adopt the SNA methodology.

\section{A network perspective of environmental justice conflicts}

\subsection{Political geographies of environmental justice conflicts: sustainability, violence, criminalization}

EJ struggle dynamics and outcomes are proof of the colonial, racial, class and gender bias of the political economy forces that expand the socio-metabolic patterns of industrial systems (Gleeson \& Low, 2002; Nixon, 2011; Pellow, 2004). It is an expansion that constantly reshapes the political geography of the commodity frontiers (Conde \& Walter, 2014, pp. 71-74; Moore, 2000, pp. 409-433), and provokes clashes between different socio-metabolic configurations causing environmental conflicts, both on extractive and disposal sites (Bullard \& Johnson, 2000; D'Alisa \& Demaria, 2013; Demaria \& Schindler, 2016; Scheidel, Temper, Demaria, \& Martínez-Alier, 2018). Because of the unequal distribution of benefits and costs of socio-environmental changes (Pellow, Weinberg, \& Schnaiberg, 2001), some scholars had defined such conflicts as ecological distribution conflicts (Martinez-Alier, 2002; Martínez-Alier \& O'Connor, 1996). However, political ecologists and geographers have pointed out that EJ has never simply been a meter of distributional justice; they have demonstrated that the multiple and contested spatialities at play in EJ struggles imply of course geographies of unwanted land uses but also geographies of differentiated responsibilities, geographies of misrecognition and of exclusion (Schlosberg, 2013; Walker, 2009).

Furthermore, Marxist geographers and political ecologists have criticized those EJ frameworks that are too focused on a specific geographic scale and that favor specific locales against the necessity to generalize the claims of environmental and social movements (Swyngedouw \& Heynen, 2003). More decisively they have criticized those EJ scholars that embrace a liberal and distributional perspective of justice (Swyngedouw \& Heynen, 2003; Velicu \& Kaika, 2017). According to these authors, a more effective concept of justice should be based on political equality that emphasises the capacity of the oppressed to enact 
and perform just socio-ecological configurations and imaginaries (Velicu, 2019).

Geographers have developed political analyses of the multiple spatialities of EJ struggles expanding horizontally i.e. beyond the dispute around the unwanted land uses, and vertically, i.e. beyond the environmental struggle of specific localities (Towers, 2000, Walker 2010; Schlosberg, 2013). One of these substantive extensions was the link between sustainability and EJ movements (Agyeman \& Evans, 2004; Schlosberg, 2013; Walker, 2009). The study of the performative capacity of EJ movements to promote ecologically sound and socially equal transformations is gaining a new momentum (Temper, Demaria, Scheidel, Del Bene, \& Martinez-Alier, 2018). The forefront of EJ scholarship engages more and more with the politics of transition which struggle against the capitalist world in which they are embedded and promote more sustainable socio-ecologies to live in (Scheidel et al., 2018).

However, while from this point of view, environmental defenders and EJ organizations should be considered as fundamental social forces for just and ecologically sounds transitions, very often they are persecuted, criminalized and killed (Global Witness, 2016; Hill, 2016; Scheidel et al., 2018). Violence against and criminalization of environmental activists is not new for radical geographers and political ecologists (Peet, Robbins, \& Watts, 2010; Peluso \& Watts, 2001); the increasing cases of environmental conflicts mapped by activists and scholars worldwide ${ }^{3}$ and the pervasiveness of environmental crime (Sollund, Stefes, \& Germani, 2016) is fostering new interests in the form and dynamics of violence, repression and criminalization that is occurring as a consequence of environmental resource extraction, dispossession and disposal.

As proof of this renewed interest, one can read the contents of the recent special issue that Temper et al. (2018) have edited. The several contributions offer an overview of the EJ movements and investigate the role of environmental defenders in promoting just sustainability transformation. Three out of twelve articles deal directly with the issue of violence (Del Bene, Scheidel, \& Temper, 2018; Mingorría, 2018; Navas, Mingorria, \& Aguilar-González, 2018).

Mingorría (2018) analyzes the oil palm and sugarcane expansion in Guatemala. She shows how the State apparatus has favored agro-industrial interests and weakened the alliance between NGOs and peasants which were criminalized and subjected to systematic violence. Del Bene et al. (2018) investigate how the demand for renewable energy is renewing a worldwide interest for hydro-power installations. Analyzing 220 cases of dam-related conflicts, the authors show that the quest for renewable energy risks replicating the pattern of repression, criminalization and violence typical of other extractive-related activities and cutting off the emergence of ecologically sound socio-economic arrangements. Last but not least, Navas et al. (2018) develop a multidimensional approach for grasping the different forms of violence used in environmental conflicts. They propose a concept of violence that encompasses: direct violence (e.g. murder, imprisonment), structural violence (e.g. criminalization, institutional failings), cultural violence (e.g. racialization, ideological accusation), slow violence (soil contamination, emergence of illness), and ecological violence (e.g. biodiversity loss, disruption of ecosystem functions). They analyze 95 environmental conflicts in Central America and show that different typologies of violence can appear in different moments of conflicts and in different geographies. They describe how different forms of violence overlap and coexist as conflict evolves. The authors emphasize that EJ movements and organizations often emerge in response to a long-lasting and multidimensional process of violence, not the other way around.

Not only for scholarly reasons but to support those actors that compose the core force for just and sustainable transformations (Scheidel et al., 2018), it is increasingly important to study and

\footnotetext{
${ }^{3}$ See https://ejatlas.org/.
}

understand the dynamics and the structural composition of those EJ movements that are able to rearticulate their struggles and claims when violence and criminalization try to silence them. With this study, we aim to contribute to this challenge. Before showing how, let us present Campania's case and contextualize it within waste-related environmental conflicts.

\subsection{Framing the socio-environmental conflicts in Campania}

Martin Luther King was killed in Memphis when he went to support striking black waste and sanitation service workers. To some EJ scholars this connects the Civil Rights movement, EJ movements and wasterelated conflicts (Bullard \& Johnson, 2000). Landmark books for the development of EJ framework have dealt with waste conflicts and toxic disposal in poor and racialized spaces worldwide (Pellow, 2004, 2007).

As part of the 'garbage wars' (Pellow \& Naguib, 2002) occurring worldwide, the struggle against incineration, waste trafficking and mismanagement in Campania has been framed as an EJ movement (Armiero \& D'Alisa, 2012; D'Alisa \& Armiero, 2011). This struggle has implicated the abuse of state of emergency power (Iannello, 2007, pp. 137-179), the systemic exclusion of citizens from the decision making process (D'Alisa et al., 2010), the racialization of Campania's inhabitants legitimized by political discourse that blames their laziness and uncivil attitude (Petrillo, 2009, pp. 17-71), the creation of "sacrifice zones" and the targeting of low-income and peripheral communities (De Biase, 2015), and a disjunction between government representatives, corporate executives and professional observers' discourses and the perceptions of Campania citizens with regard to the causes of their unhealthy condition (Abbot, 2014; D'Alisa et al., 2017). Using the political geography lens (Towers, 2000; Walker, 2009), Campania case, as many other EJ struggles, is characterized by overlapping contested geographies of spatialities and scales; the scales of regulation (and oppression) and conflicting meaning intersect with space of inequality, of misrecognized people and places, and of exclusion. Using the category of Navas et al. (2018), the activists in Campania's waste conflict have suffered through structural, cultural and slow violence.

Between 2007 and 2008, one of the most significant urban waste conflicts in Campania occurred in Pianura, in the outskirt of Naples. The Pianura landfill in the Contrada Pisani district had been operating for more than 40 years. When it was closed in 1996, it was one of the biggest dumping sites in Europe. In 2008, when the waste Commissioner decided to reopen it, riots and street violence broke out. Taking the fight to police and soldiers tasked with re-opening the landfill, an unusual alliance formed across the left-right political spectrum, passing for hooligans (the so-called Neapolitan "ultrà"), and forced the Commissioner to look for a different dump site for the waste accumulated in the streets (De Biase, 2015).

In response to this, national authorities changed their political tactics. The Pianura riots demonstrated that direct confrontation with protesters was a losing maneuver. To prevent organized activities and to criminalize those citizens that opposed governmental measures, Decree n. 90 (Law n. 123/2008) not only imposed the opening of ten new landfills and the construction of four new incinerators, it threatened the immediate imprisonment of citizens that obstructed the implementation and the functioning of waste facilities. Waste plants and landfills were declared sites of "strategic State interest"; thus citizens that actively opposed the waste plan might be committing crimes against the State.

The authoritative drift of waste policies and the use of the army to clean the streets proved an effective deterrent; the threat of imprisonment and the criminalization of protests stifled the waste movement (D'Alisa et al., 2010). But these measures did not definitively debunk it. The activists used the circumstances to re-organize their force, re-think their strategy and reformulate their narrative. Public authorities re-designed and demarcated scale of regulations (and oppression) meant to intentionally limit the Campania activists (Jonas, 1994; Towers, 2000), and relegate their activities to specific militarized and 
criminalized localities. However, the scalar reframing (Kurtz, 2002) of Campania activists was able to map new strategies out of their struggle and to challenge the authorities with a counter frame that rearticulated multiple layers of material injustices.

The waste conflict in Campania cannot be considered an EJ success, but recent studies have shown several achievements (Armiero \& Sgueglia, 2019; Caggiano \& Rosa, 2015; D’Alisa et al., 2017; De Rosa, 2018; Vagliasindi, Lucifora, \& Bianco, 2015). In November 2013, for example, the massive mobilization in Naples forced the national legislator to declare the burning of waste a crime (Law Decree 136/2013), while before it was considered only a misdemeanor, as the vast majority of the environmental crimes before the approval of the Bill 1345 (Vagliasindi et al., 2015). It also had indirectly contributed to introduce a new title in the Italian penal code dedicated to environmental crime (D'Alisa et al., 2017). Italian parliamentarians have been discussing for decades the introduction in the penal code of different classes of environmental crimes. Eventually, the waste movement in Campania and its struggle against environmental crimes sped up the approval of the Law 68/2015 (ex Bill 1345) that enriched the Italian penal code with four environmental crimes.

Caggiano and Rosa (2015) show how the struggle against waste-related crime has contributed to new alliances between waste-related EJ organizations and social cooperatives that cultivate organic products on land confiscated from the camorra. The latter is example of re-territorialization that resists environmental degradation while trying to influence transformative socio-ecological dynamics (De Rosa, 2018). In the same vein, Armiero and Sgueglia (2019) demonstrate how Campania's waste activists promoted new urban commons, collective production of organic food and wine and land stewardship against camorra abuse and contamination. Moreover, they were able to politicize their actions and to link the reshaping of their own local geography to far-away global struggles against predatory capitalist practices (Towers, 2000).

These achievements are proof that in Campania the environmental activists are a just force for transition. As in other places, where EJ organizations have tackled waste-management problems and supported sustainable transformations (Weber, Calaf-Forn, Puig-Ventosa, Cabras, \& D'Alisa, 2018), Campania's waste-related grassroots organizations contribute to the raising of public awareness about ecological predicaments and to the implementation of environmental measures at different scales.

However, still deserving of further analysis are the structural properties and composition of the waste-related EJ organizations in Campania and how, under circumstances of repression and criminalization, they reorganize and progress towards social justice and ecologically sound transformations. This is the gap we aspire to fill by studying the Campania's waste conflict from the perspective of Social Network Analysis (SNA).

\subsection{Social Network Analysis and environmental justice scholarship}

SNA enables scientists to analyze structural composition and relational components of evolving systems that cannot otherwise be identified using other techniques (Nugroho \& Saritas, 2009; Wasserman \& Faust, 1994).

Geographers are increasingly using SNA because it allows them to investigate complex economic, social and environmental relations between different actors and provides insights into the political and geographic implications of these relations (see for examples: Poon, Tan, \& Hamilton, 2019; Radil \& Walther, 2018; Wanke \& Falcão, 2017). According to EJ scholars (Schlosberg, 2014) networking strategies represent the organizational strength of the EJ movement since its early manifestations, the networking effect being one of the explanations of how struggle against locally unwanted land uses have sometimes changed the scale of EJ claims (Towers, 2000). However, EJ scholars have not paid much attention to the potential of SNA. To our knowledge only Aydin, Ozkaynak, Rodríguez-Labajos, and Yenilmez (2017) have used this tool to empirically investigate the network effects in EJ conflicts. They analyze 346 mining conflicts around the world and reveal the main features of environmental conflicts perceived as successful. They conclude that those characteristics depend on two factors: the number of NGOs directly involved in the conflict, and the tight interconnection between peripheral and central actors of the network. They emphasize the importance of local movements for developing a network of relations on multiple scales with national and international actors providing further leverage for local activism. They studied the patterns across cases and contexts. However, they did not investigate the evolution of a particular conflict across time and how a particular environmental movement can achieve, if not full success, a series of important goals. Thus, they did not explain if particular EJ movements obtain victory, even during moments of hard repression and criminalization. This is what we aim to do with our Campania case.

Some scholars suggest that well-connected actors are able to mediate, coordinate and mobilize more efficiently against threats (De Nardo, 2014). Others underline the importance of studying: i) the tight interdependence of single components of the networks (Ackland \& O'Neil, 2011), and ii) the multiple levels of interaction among the different actors that belong to certain networks of relations (Bosi, Giugni, \& Uba, 2016). Following these insights, we aim to enrich the empirical perspective of the EJ framework by showing the inner dynamics of networking that grassroots movements forged among diverse group of actors that are subjected to repression and criminalization. We do this looking at waste management conflict through the lens of relational networks. We offer a representation of the waste-related movements in Campania before and after a turning point to investigate how it evolved over time. Our approach enables us to associate the resurgence of an EJ movement to its capacity: i) to change the structure of its networks, ii) to generate multiple level of interactions across networks iii) to improve the tightness of its components.

\section{Methods and materials}

\subsection{SNA methodology}

The SNA provides a formal and visual method of assessing the structure of interconnected nodes (i.e. a social network) and the nature of their relation. More specifically, it can enable one to: (i) visualize the network of relations under study, ii) ascertain its core components i.e. nodes (e.g. actors versus events); (iii) investigate the characteristics of the network's nodes profiling the actors by means of their attributes (e.g. lifestyle, state of health); (iv) examine its structural properties in terms of robustness (e.g. number of ties, density, inclusiveness, etc.) and vulnerability (e.g. the existence of cut-points); v) compare the architecture of the networks in different moment of time (e.g. before and after a particular occurrence i.e. a turning point).

In order to study the structural properties of the networks we employed five indicators of network cohesion. First, the number of ties, i.e. merely the number of edges ignoring the direction of arcs (Wasserman \& Faust, 1994); second the inclusiveness, i.e. the number of connected nodes expressed as a proportion of the total number of potential nodes (Morone, Falcone, \& Tartiu, 2019); third the density i.e. the ratio of the number of ties to the number of possible ties in a network. It referred to the proportion of potential connections in a network that were actual connections (Butts, 2008). Fourth, the clustering coefficient that represents the proportion of actual ties amongst a node's neighbors to the maximum possible number of such ties (Ozkan-Canbolat \& Beraha, 2016). Fifth, the average degree that could be expressed as the number of incoming ties (the in-degree) and/or the number of outgoing ties (the out-degree) (Huh \& Lee, 2011). Finally, we also look at the vulnerability of the networks through a cut-point analysis. A cut-point is the pivotal point of articulations between the elements that make up a network. It indicates some types of local centrality. The absence of 
cut-points implies that communication and exchanges among the members of a component are not dependent upon anyone.

\subsection{Questionnaire and sampling}

In order to develop the above described SNA, we drafted a questionnaire and administered it to actors that we selected using the snowball sampling method. ${ }^{4}$ In 2014 during six months of fieldwork in Campania, we conducted 34 face-to-face semi-structured interviews with opinion leaders (i.e., core actors of the network). ${ }^{5}$ We interviewed different activists, ranging from those formally engaged in the dispute (i. e., by means of their submission of written appeals to the Italian Republic President or formal complaints to the Courts, etc.) to those substantially struggling against the waste mismanagement conflict (i.e., by means of their participation in marches, blogs, newspapers, broadcasts, etc.). Following the snowball method, we asked each opinion leader to suggest names of other activists who they believed had played a relevant role in the struggle. We stopped searching for EJ actors to interview when our interviewees began suggesting names of activists that we had already interviewed.

The questionnaire was composed of four parts designed to gather information on: 1) actors' socio-demographic profile; 2) actors' environmental behavior and attitudes; 3 ) the type of relations the actors had undertaken during their activism with relevant organizations (e.g. local committees and environmental NGOs; research and health centers; and public authorities); 4) actors' perspectives on environmental crimes.

\subsection{Affiliation networks}

The information of the third part of the questionnaire was fundamental for building up our networks, whose nodes can be distinguished in actors i.e. opinion leaders and other activists, and events, i.e. organizations. Following the approach of Morone, Tartiu, and Falcone (2015), we draw three different kinds of relations between the actors and the events. We call these relations affiliation networks. First, actors can be members of one or more events; second, these actors could be linked to events to exchange information (e.g. opinions about contamination sites, ideas about how to organize the next march); third, actors could connect with events in order to acquire substantial knowledge (dossiers, waste plans, epidemiological studies). Consequently, we defined three diverse networks of relations: 1) "Affiliation Membership Network (AMN)", 2) "Affiliation Information Networks (AIN)", and 3) "Affiliation Knowledge networks (AKN)".

AMN was thought to represent the tightest bond between actors and events since being a member of an event entails active involvement in most of the activities that the event promotes (e.g., meetings, protests, roundtables, public assemblies, the writing of press release, letters and/ or dossiers). AIN's actors, on the other hand, were thought to embody a weaker link with an event when compared with AMN's members. However, AIN still implies the physical involvement of the actors, i.e. face-to-face interactions (tacit information) with activist from other events. Indeed, AIN's activists might participate in and support initiatives of a particular organization (i.e., marches, demonstrations, sit-in, seminars etc.), even though they are not members of it. Such informal interfaces are very important for the diffusion of information among activists and the exchange of ideas about the most effective actions to undertake and how to reach common strategic objectives (e.g. to impede the opening of new landfill and the building of an incinerator; to force a change of regulation or laws, to push for the launch of an epidemiological study). Finally, AKN was thought to depict a loose interface

\footnotetext{
${ }^{4}$ Snowball sampling consists of two steps: first, identifying potential subjects in the population and, second, asking those subjects to recruit other people. ${ }^{5}$ Opinion leaders are those influential people that exert a certain degree of influence over others.
}

among actors and organizations since the aim is mainly to acquire knowledge from codified sources without much human interaction or sharing of common goals. Activists may consider it very important to acquire studies, research, and reports from organizations with which they do not directly interact or regularly confront. For instance, to better substantiate their claims and proposals, activists might acquire waste plans, dossiers, dataset, epidemiological studies and other official documents released by the governments that they are struggling against.

To study how the architecture of the three networks changed across a turning point, we asked interviewees to indicate which types of relations they had with organizations in the periods 2000-2008 and 2008-2014, so as to highlight the structural properties of the networks both before and after the 2008. All data were elaborated and managed using the UCINET6 software, which allowed us to derive 10 different socio-grams through its incorporated visualization software NetDraw.

\subsection{Campania case-study}

Campania is the southern Italian region whose capital is Naples (Fig. 1). Campania spans $13,590 \mathrm{~km}^{2}$ and has $350 \mathrm{~km}$ of coastline along the Tyrrhenian Sea. At the end of 2014, the region had a population of 5.9 million, making it the third most populous region in Italy (ISTAT, 2016). Most of the population is concentrated in the metropolitan area of Naples, a complex urban-rural system of 4 million inhabitants that also encompasses a part of the province of Caserta (Fig. 1); less than the $40 \%$ of the territory where the $80 \%$ of total population is concentrated (Smarrazzo, 1999). It is among the poorest of Italy's 20 regions; its GDP per capita in 2015 was $€ 17,200$, whereas the national average was $€ 27$, 000 and the southern Italy average was $€ 17,800$ (ISTAT, 2016). ${ }^{6}$

Thousands of contaminated sites affect the salubrity of this urbanrural complex (ARPAC, 2005). The presence of several legal and illegal disposal sites further increase significantly the biophysical pressure of the area (D'Alisa, Di Nola, \& Giampietro, 2012). Campania Felix, as the ancient Romans defined that part of the Campania region that sits between Naples and Caserta provinces, is characterized by an extraordinary fertility, but it has been strongly affected by the illegal disposal of toxic waste since the 1980s. In the last decades it has become known as the "Land of Fires" (Legambiente, 2003; Saviano, 2006). In the 1990s the "Land of Fires" (see Fig. 1) referred to three cities within the province of Naples. After a decade of activists claiming the area was vaster, the national parliamentarians institutionalized the Land of Fires (LoF hereafter) by approving the Law 6/2014. 53 cities became part of the LoF. However, more than an administrative area, the LoF represents a phenomenon of illegal waste dumping that serves a reduction in costs for legal businesses operating at larger scale (D'Alisa et al., 2017). The LoF is the result of two inter-related processes. First, the Italian national government's waste emergency proclamation in Campania in 1994, which divested the regional government of its legal power and established an ad-hoc agency, i.e., the Committee for the urban waste emergency in Campania that was assigned special legal power to solve the crisis. Second, the systematic practice of illegal dumping perpetrated by a criminal partnership of legal business, camorra families and members of the state apparatus that has dumped tons of toxic and hazardous waste in Campania's countryside for decades (D'Alisa et al., 2010; Iacuelli, 2008; Petrillo, 2009, pp. 17-71).

Though there is no definitive agreement among epidemiologists on the causality between illegal waste dumping and an increase morbidity and mortality in the area (Capocaccia, Comba, Conti, \& De Angelis, 2012), several studies show that in Campania there has been an anomalous increase of certain pathologies that may be related to its waste-related contamination (Fazzo et al., 2008; Martuzzi et al., 2008).

The proliferation of illegal waste practices was exacerbated by the fact that, prior to 2001 (with Law 93/2001), the Italian legislation

${ }^{6}$ https://www.istat.it/it/archivio/regioni. 

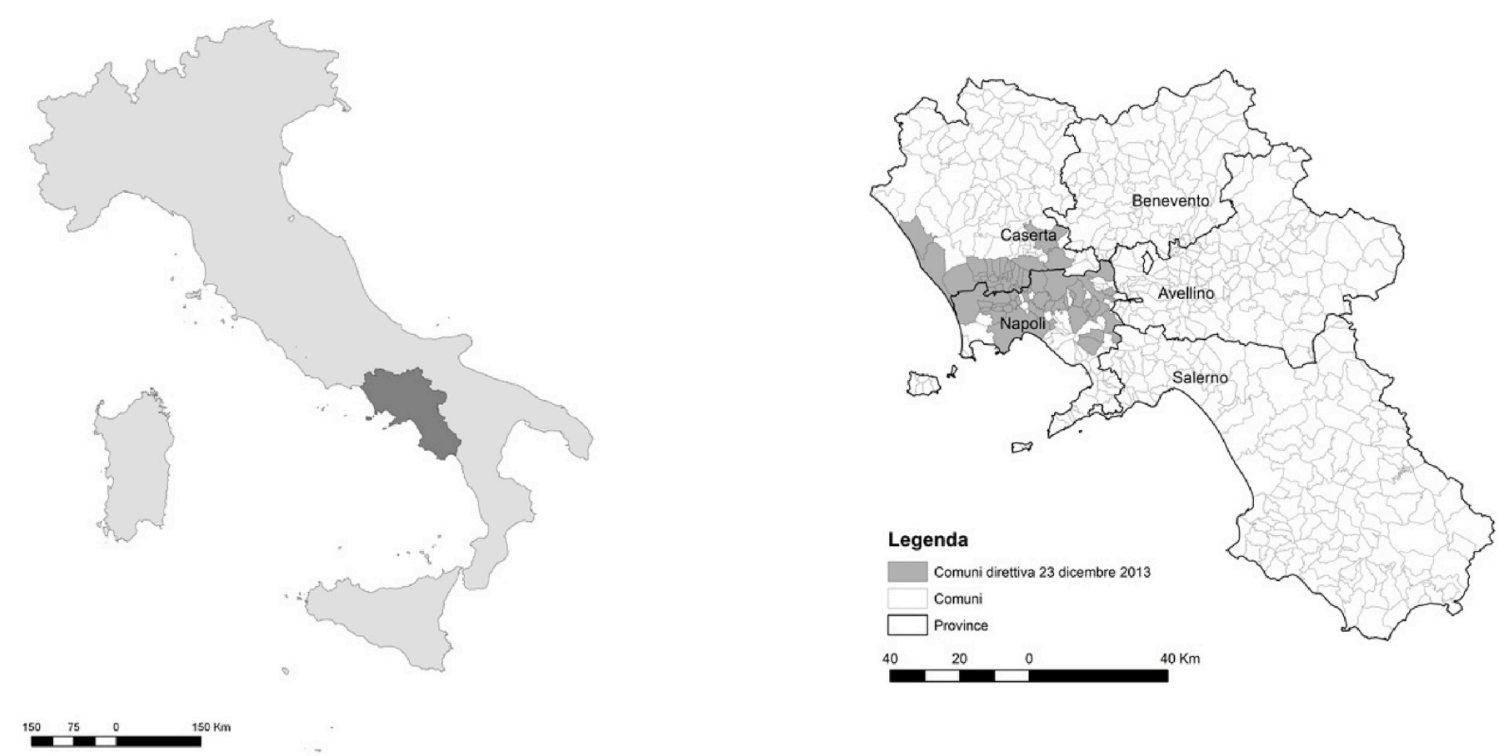

Fig. 1. Campania region's main geographical features.

Source: http://www.minambiente.it - Land of Fires map elaborated by David Burgalassi (personal concession).

considered illegal waste-related activity a misdemeanor. ${ }^{7}$ The same was true for the burning of toxic waste, which environmental organizations started to systematically denounce in 2003 (Legambiente, 2003); the legislators only recognized it as a crime in 2013 (Decree 136/2013). The lenient sanctions and soft enforcement approach that was adopted for many years made illegal waste activities appeal to corporations; Franco Roberti, the ex-Italian Anti-mafia Prosecutor, often maintains that such illegal waste-related activities should be considered a corporate crime more than a mafia-like crime ${ }^{8}$ (see also: de Falco, 2014).

\section{Results and discussion of the waste-related environmental movement in Campania}

\subsection{The actors of the networks}

We conducted 34 interviews with opinion leaders and core activists of the waste movements in Campania. 56\% are men and $44 \%$ women (Table 1a), their age ranged from 23 to 62 years old even if most of them (44\%) were between 25 and 40 years old (Table 1b). More than $40 \%$ had obtained a university degree (Table 1c). On average actors' household composition consisted of 3 members. $62 \%$ of them lived in a house owned by one member of the family, more than $30 \%$ declared a family income of less than $€ 15,000$.

All respondents declared that they had taken part in activities that promote sustainability, such as participating in EJ organizations and movements (95\%); separating waste (100\%); trying to not waste food, water and energy (97\%); and utilizing public transportation or biking, rather than driving (52\%). Almost $90 \%$ reported living close to a waste facility (i.e. an incinerator, a recycling plant, a legal or illegal landfill, etc.) and $99 \%$ considered themselves victims of waste-related environmental crimes. The $66 \%$ that declared to have no trust in political authorities and organizations did so at different scales (i.e. local, national and supranational). More specifically, respondents had recently engaged in environmental activism (after 2011) because they felt they had been

\footnotetext{
${ }^{7}$ Law 93/2001 recognized the organized activity of illegal waste trafficking as an environmental crime.

${ }^{8}$ Hearing with National Anti-Mafia Prosecutor Franco Roberti. Parliamentary Commission on the Waste Cycle and Connected Illegal Activities; XVII legislature.
}

Table 1

(a, b, c). Sample statistics.

\begin{tabular}{|c|c|c|}
\hline \multicolumn{3}{|l|}{ a } \\
\hline Gender & $\mathrm{N}^{\circ}$ & $\%$ \\
\hline Male & 19 & 55.9 \\
\hline Female & 15 & 44.1 \\
\hline Total & 34 & 100 \\
\hline \multicolumn{3}{|l|}{$\mathrm{b}$} \\
\hline Age & $\mathrm{N}^{\circ}$ & $\%$ \\
\hline$<25$ & 2 & 5.9 \\
\hline $25-40$ & 15 & 44.1 \\
\hline $40-50$ & 8 & 23.5 \\
\hline$>50$ & 9 & 26.5 \\
\hline Total & 34 & 100 \\
\hline \multicolumn{3}{|l|}{ c } \\
\hline Education & $\mathrm{N}^{\circ}$ & $\%$ \\
\hline None & 0 & 0 \\
\hline Primary school & 1 & 2.9 \\
\hline Secondary school & 15 & 44.1 \\
\hline University degree & 15 & 44.1 \\
\hline Ph.D. & 3 & 8.9 \\
\hline Total & 34 & 100 \\
\hline
\end{tabular}

victims of environmental crime and mistrusted political organizations.

The 34 interviewees (actors) named 33 events (organizations) with which they had varying degrees of connection. They interacted with other actors of the events that they are member of (see Fig. 2); but in order to exchange information and strategies for their common struggle and produce effective mobilization and knowledgeable proposals they also connected with actors of events that they were not member. Finally, they access to documents, plans and studies of events that they oppose such as the Committee for Waste Emergency in Campania that often imposed the waste plan that the activists disapproved (more on this in the next section).

We also characterized the 33 actors by two attributes, namely, lifestyle and health. The questions related to lifestyle aimed to delineate their habits and attitudes towards smoking cigarettes, diets and drinking alcohol. On the other hand, to investigate the activists' health 


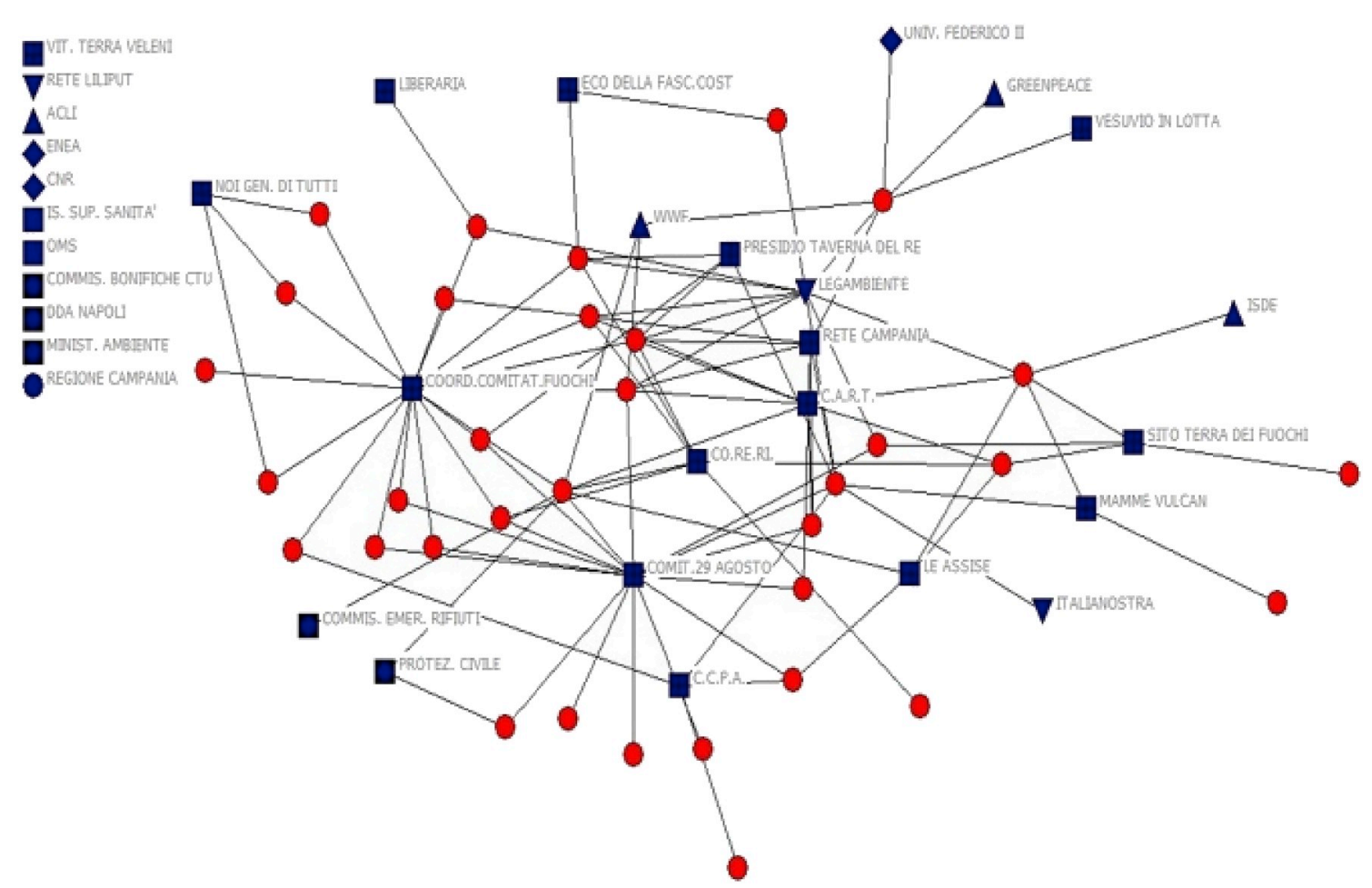

Fig. 2. Affiliation membership network 2008-2014.

Legend: Red circle $=$ actors i.e. activists; blue = events i.e. organizations (box = local associations; upside-down triangle = national organizations; triangle $=$ international organizations; diamond = research centers; square = healthcare institutions; circle = public bodies). Source: authors' elaboration.Note: Those nodes that are listed on the left of the graphs are not part of the visualized network.

conditions, we asked if in the last decades they, or a component of their family, or any friends of theirs, had contracted serious illness such as asthma, respiratory difficulties, disorders of the circulatory system, and/ or cancer.

In Figs. 3 and 4, we report the attributes, of the actors in the AMN, respectively, the lifestyle and health. At first glance, one can note that most activists in the network claim to have a very or good lifestyle (very small and small red circle in Fig. 3), i.e. they declared having a healthy diet and not to smoke or drink alcohol very much. Only three of them (big red circle in Fig. 3) declared to conduct a very harmful lifestyle.

At the same time, the actors occupying a central position in their everyday life are those that live with the disease (Fig. 4); 24 out 34 activists were seriously ill or had a close family member - e.g. mother/ father, son/daughter, wife/husband, sister/brother that was (big and medium red circle in Fig. 4). None declared not having at least a friend that was harmfully sick. Thus, among our interviewees, the more you have been affected or/and some of your close relatives is ill, or has died, because of a serious disease the more active you are; likewise, the healthier your current lifestyle is the more active you are.

\subsection{The affiliation networks and the turning point}

The affiliation networks presented below are characterized by 67 nodes, 34 of which are the actors (activists) and 33 the events (organizations) that at least one of the actors has declared to be linked with after and/or before the turning point (2008). 15 out of the 33 organizations are local associations whose scope was to struggle against the causes and the effects of the urban mismanagement and illegal trafficking of industrial waste in Campania (e.g. 29th August Committee, Campania Network for Health and Environment, Coordination Fires Committee); 7 national or international NGOs, mainly environmental and medical associations (e.g. Legambiente, Italia nostra, WWF, Greenpeace, ISDE) 2 national public research centers (CNR and ENEA), 2 health research centers (ISS and WHO) and 6 public authorities (e.g. Commissioner to
Waste Emergency in Campania, the Department of Civil Protection, Ministry of Environment, Campania Regional Government).

The network of relations each actor had with the different events had changed over time, so the structure of the affiliation networks has different characteristics before and after 2008. Furthermore, many actors only started to be member of local associations in 2011. Looking at Fig. 5, it is clear indeed that 19 (out of 34) actors were not members of any event; thus, they were not directly involved in the waste struggle before the turning point, but they became opinion leaders or core activists of the movement after (Fig. 2).

In Table 2 are synthesized the key indicators of the AMN both before and after the turning point. The network became much more connected after 2008. Both the number of ties between the nodes and the density of the network increased almost three times. These changes had a significant effect on the network structure; indeed, the AMN before 2008 (Fig. 5) shows four subsets of networks disconnected between each other, while after 2008 (Fig. 2) all the involved actors were actively connected via organizations they were member of. The inclusiveness index increase from $38.8 \%$ to $83.6 \%$, leaving out only 11 events (organizations) of the AMN after the 2008 (Fig. 2), while before 2008 not only more events, precisely 14, but also, as said before, 19 actors were not part of the AMN (Fig. 5). The clustering coefficient, i.e. the measure of how many actors of those participating in the networks belong to the same events (so that they probably met much more often), was close to zero before 2008; it increased up to 0.31 after. Finally, the average degree of the network, i.e. the number of connections that on average each actor has with other actors via the events they participated in, also increases of a factor of two and a half (Table 2).

Essentially, the AMN after 2008 developed into a much more cohesive and robust network; the number of actors and the events that composed it increased considerably, and the active involvement of actors in the events' activities (e.g., meetings, protests, demonstrations, roundtables, sit-in) became more intense.

The same patterns are visible if one looks at the AIN (Figs. 6 and 7) 


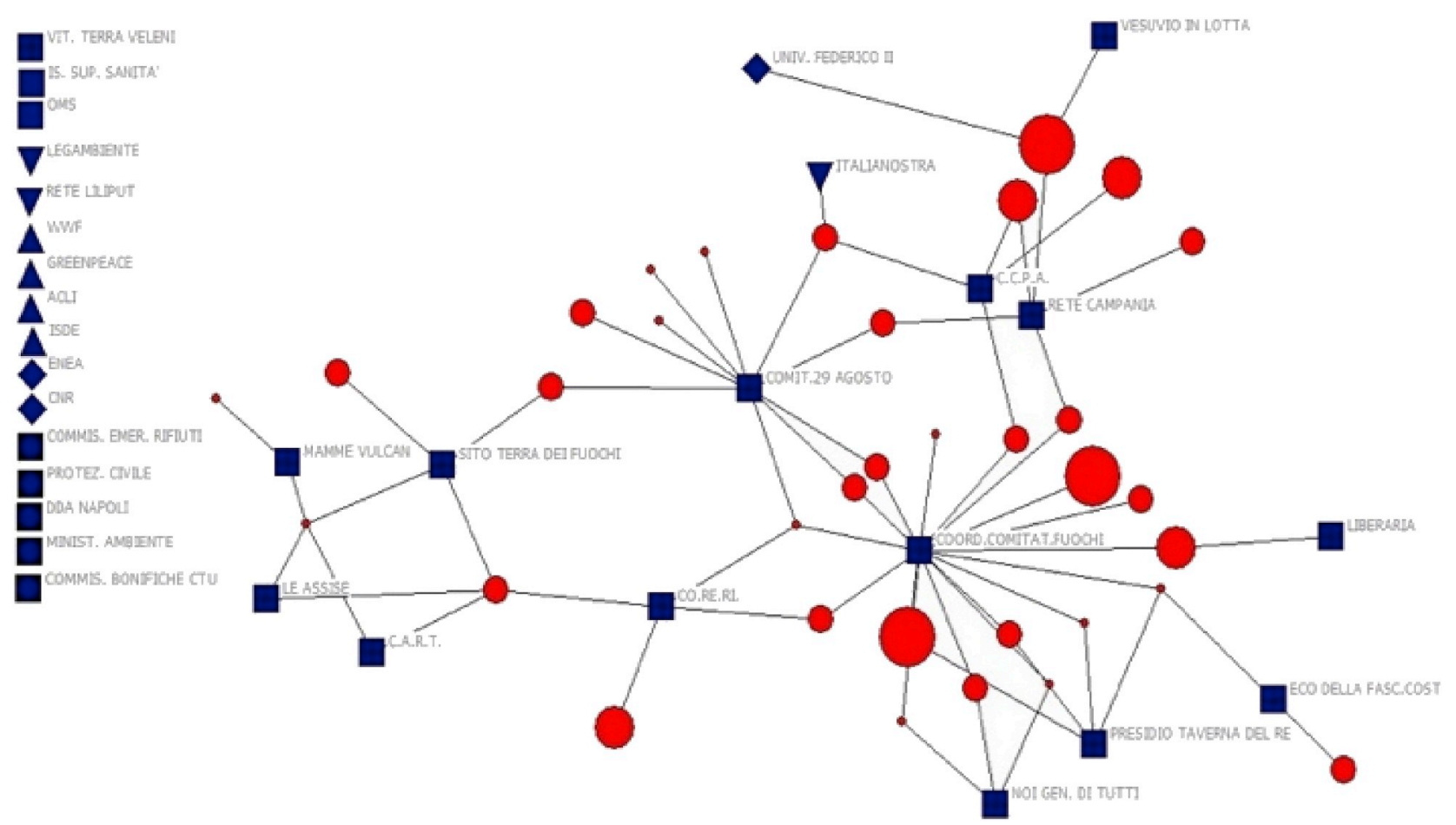

Fig. 3. Lifestyle: Attribute analysis of the Affiliation Membership Network.

Legend: the greater the size of the circle the worse the health or lifestyle attribute. Source: authors' elaboration.

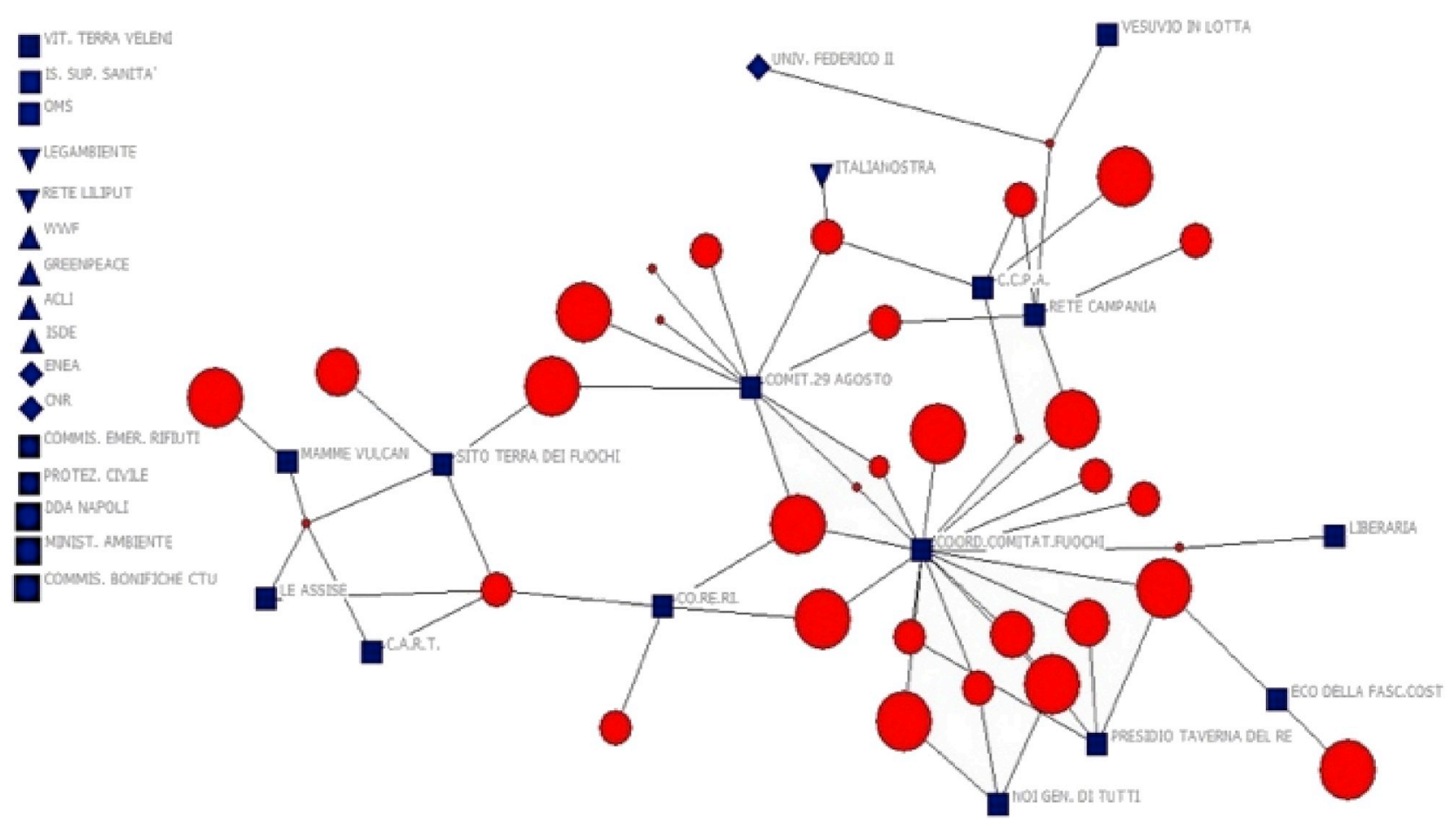

Fig. 4. Health: Attribute analysis of the Affiliation Membership network.

and the AKN (Figs. 8 and 9) before and after the turning point.

As explained in the methodology section, the Information Networks show weaker links between actors and events, and the Knowledge networks represent a loose interface between actors and events.

However, it is important to share effective strategies with other network actors for a successful environmental struggle and to acquire knowledge to prove the relevance and the viability of their proposals.
The structural improvements of both the AIN and AKN are fundamental to verify the overall organizational enhancement of the waste-related justice movement in Campania.

Looking at Table 3 , one can verify that the number of ties and the density increase of almost 4.5 times for the AIN and almost 3.5 times for the AKN after 2008, certifying the more robustness of the networks. The inclusiveness of both reach $100 \%$ after 2008 . This implies that all the 

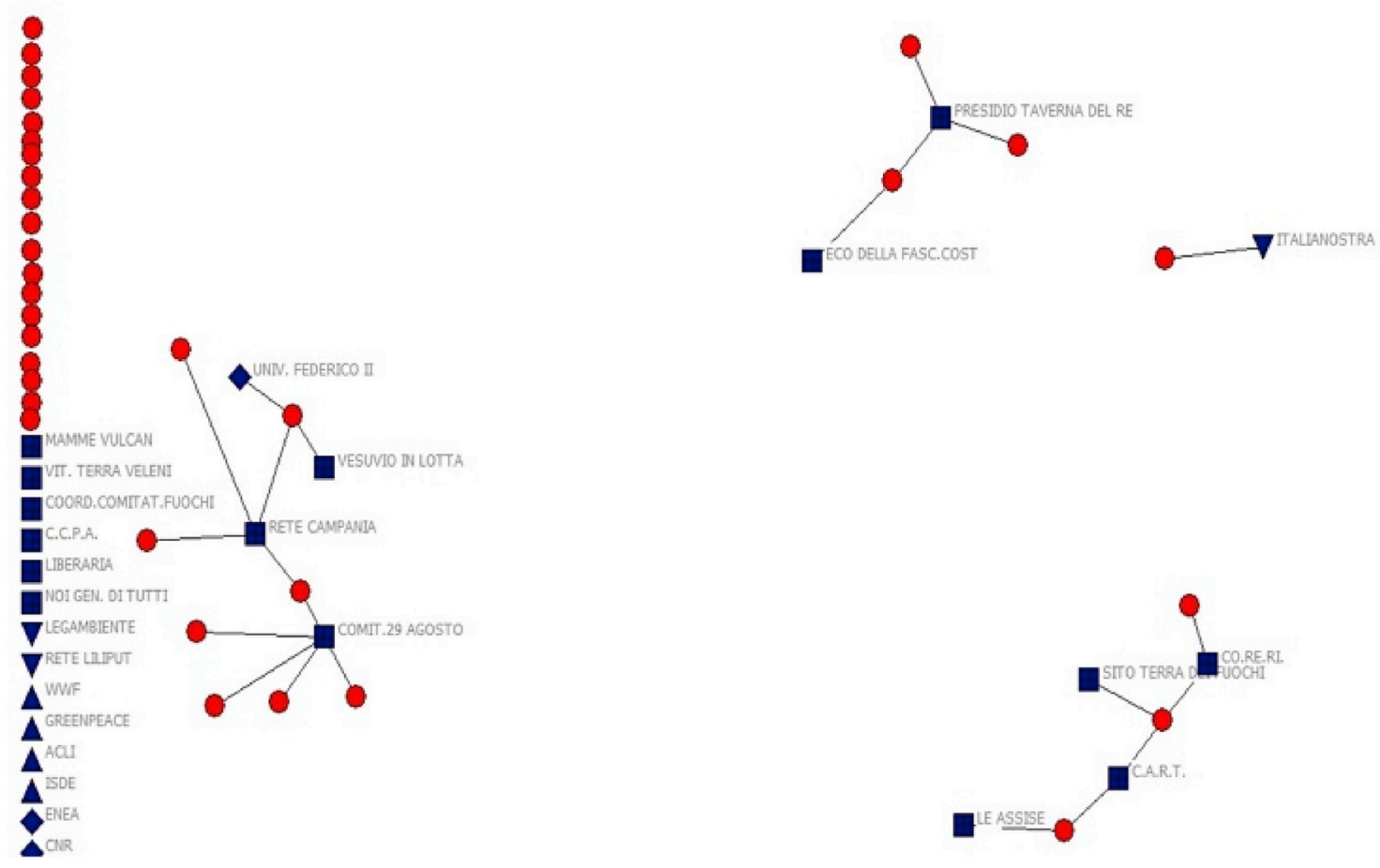

Fig. 5. Affiliation membership network 2004-2008.

Table 2

Affiliation Membership networks: Key indicators.

\begin{tabular}{lll}
\hline Key indicators & Membership & \\
\cline { 2 - 3 } & $2004-2008$ & $2008-2014$ \\
\hline Number of ties & 41 & 114 \\
Density & 0.009 & 0.026 \\
Inclusiveness (\%) & 38,80 & 83,6 \\
Clustering coefficient & 0.01 & 0.31 \\
Average degree & 0.612 & 1.701 \\
\hline
\end{tabular}

nodes (actors and events, i.e. activists and organizations) are part of the networks, and each node is linked at least with one other one. The clustering coefficients multiply for three their magnitude for both networks; thus, the actors cluster much more together around a series of events for increasing their capacity to share strategies for an effective environmental conflict, and narratives for building an alternative waste plan. They also cluster together more effectively to acquire facts, data and awareness about the causes and the consequences of mismanagement and the illegal traffic of waste.

The average degree of AIN increase by almost 8 times. It shows that after 2008 the actors met each other much more often and that they collaborated much more intensely, even if they were not members of the same events. The effect of this increase was the considerable improvement of the circulation of information in the network. The average degree of AKN tripled its value after 2008, so that for the flow of knowledge there is also a significant increase in its dissemination because the actors met and discussed much more often the results of epidemiological studies, the data of waste plans, and the contents of regulations and laws.

In sum, as it was for the AMN, also the AIN and the AKN show a more robust and cohesive web of relations among actors; the exchange of information across events, i.e. among actors that are not members of the same organization, increases considerably; also, the knowledge acquired from governmental organizations that the activists contest is not held by a few actors but circulates constantly across the network reaching directly or indirectly all the actors involved.

\subsection{The fragility of the networks: the cut-points analysis}

The results presented above show the robustness of the networks. But a robust network could be fragile if it has many vulnerable nodes. To test the vulnerability of the Affiliation Networks after the turning point, we employed a cut-points analysis. In Fig. 10 it is possible to note the presence of the key role assumed by one of the events in the AMN (yellow box).

The local organization is the main bridge among different actors and contributes to shortening the distance between them. It is a fundamental node for avoiding the isolation of several components of the AMN. If this organization would be dissolved, the network will lose its compactness and the movement will be divided into two different clusters of actors and nodes, and some actors will stop its activism.

A second cut-point exists in the network, it is a single actor (yellow circle in Fig. 10) that is a member of three different organizations. If he or she would be disconnected from the network two events will stay isolated. However, the relevance of this actor as cut-point is much less significant than the one discussed above, because the disconnection of the former will not change considerably the configuration of the network while the latter will, and with important consequences on the articulation of the waste-related movement in Campania.

The analysis of the cut-points of the AKN (Fig. 11) shows just one single activist that should she or he fall away from the network would isolate four different organizations ( 2 public bodies, a public university and a grassroots organization) from which the rest of the network could not acquire and exchange knowledge. However, the role of this actor in the AKN is quite marginal to the overall structure of the network. As we will discuss in the next section, the marginality of this actor can be explained by the fact that the knowledge he or she acquires and makes flow across the network is not core for the main claim of the movement after the turning point.

To the discussion of the above presented results we move now. In the next section we situate the analysis in the evolution of the waste-relate environmental struggle in Campania. In particular, we look at how its narrative changed after 2008. 


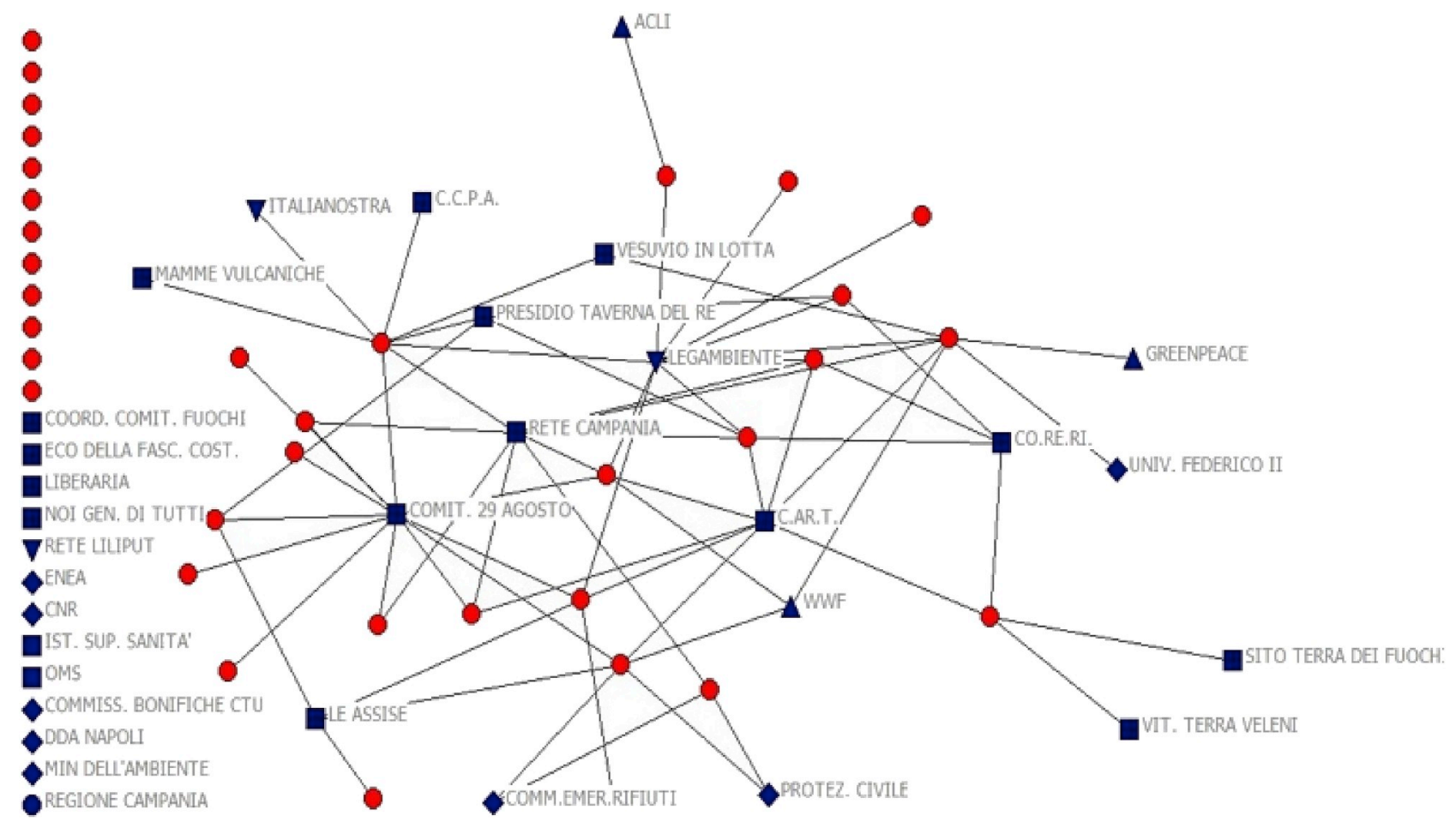

Fig. 6. Affiliation information network 2004-2008.

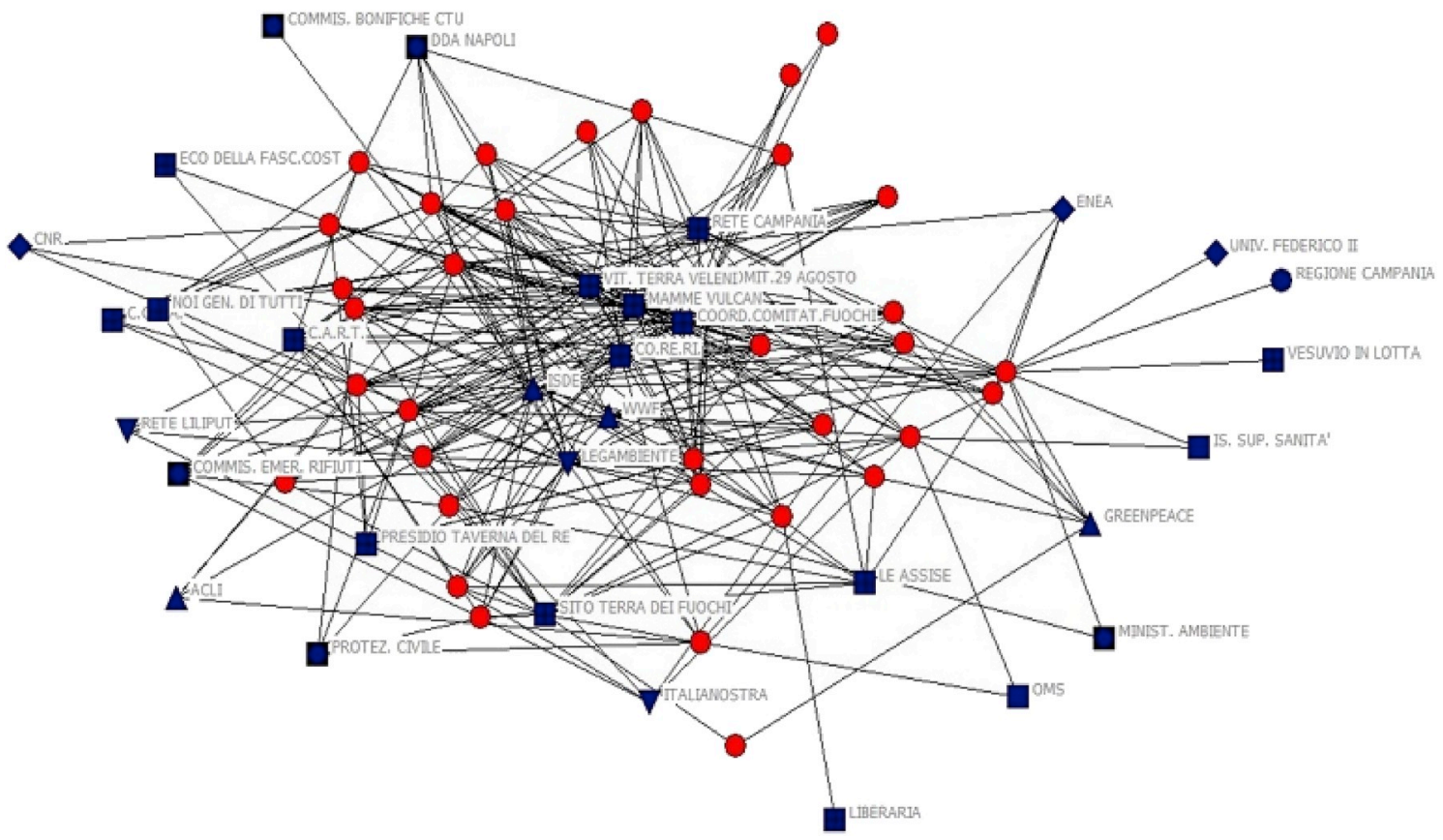

Fig. 7. Affiliation information network 2008-2014.

4.4. Discussion: the reemergence of the environmental justice movement in Campania

The waste movement in Campania before 2008 turns up as an archipelago of four disconnected subnetworks (Fig. 5). The first of these clusters, which developed around the "Comitato 29 Agosto" and Rete Campania, focused mainly on preventing the construction of the incinerator. The subnetwork whose core was the "Assise" and "CO.RE.RI"

\footnotetext{
${ }^{9}$ The extensive name in English of: a) "Comitato 29 Agosto" is Women Committee of 29th of August; b) "Rete Campania" is Campania Network of Environment and Health; "Assise" is Assembly of the city of Naples and of Southern Italy; "CO.RE.RI" is Waste Regional Coordination.
} 


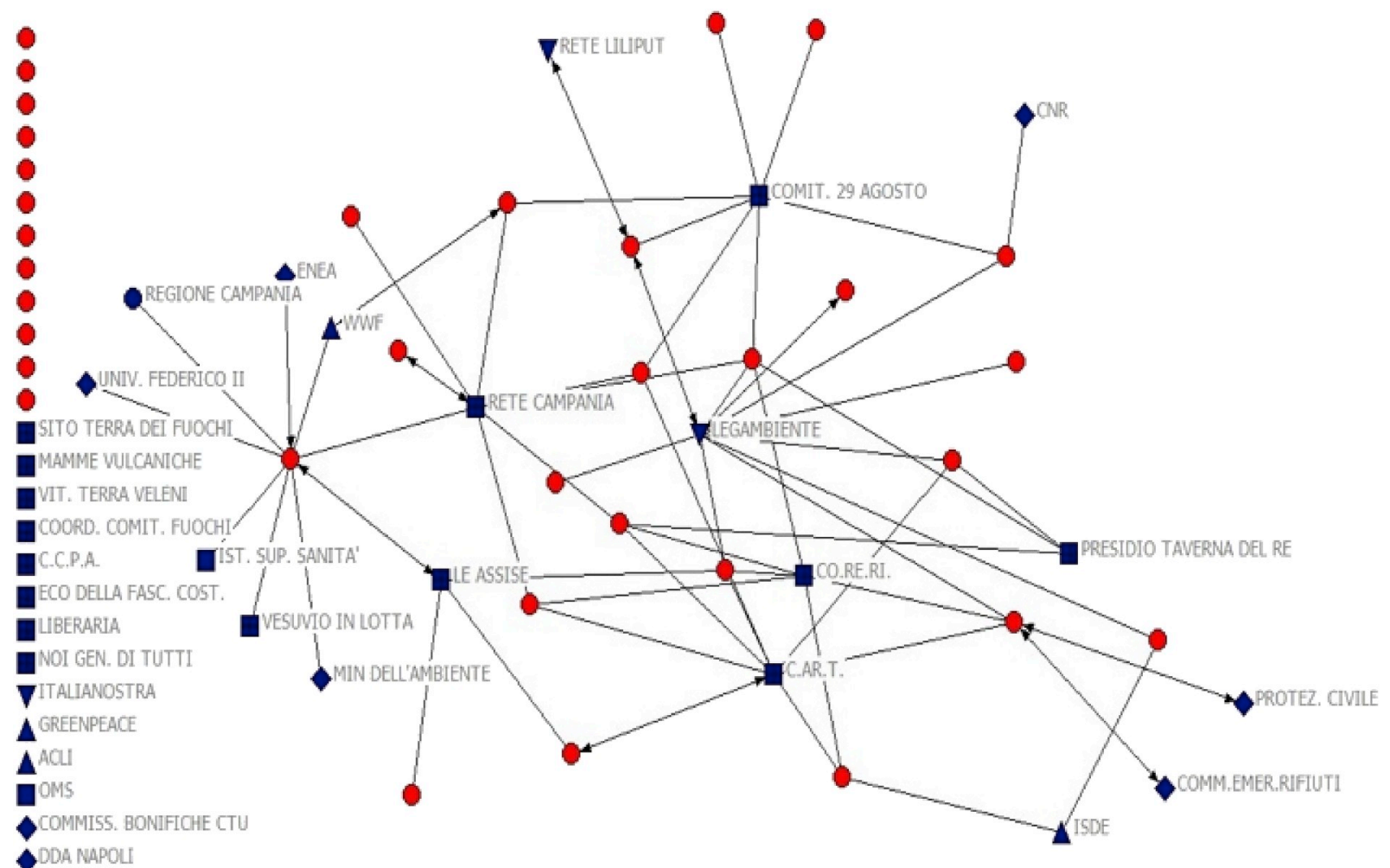

Fig. 8. Affiliation knowledge network 2004-2008.

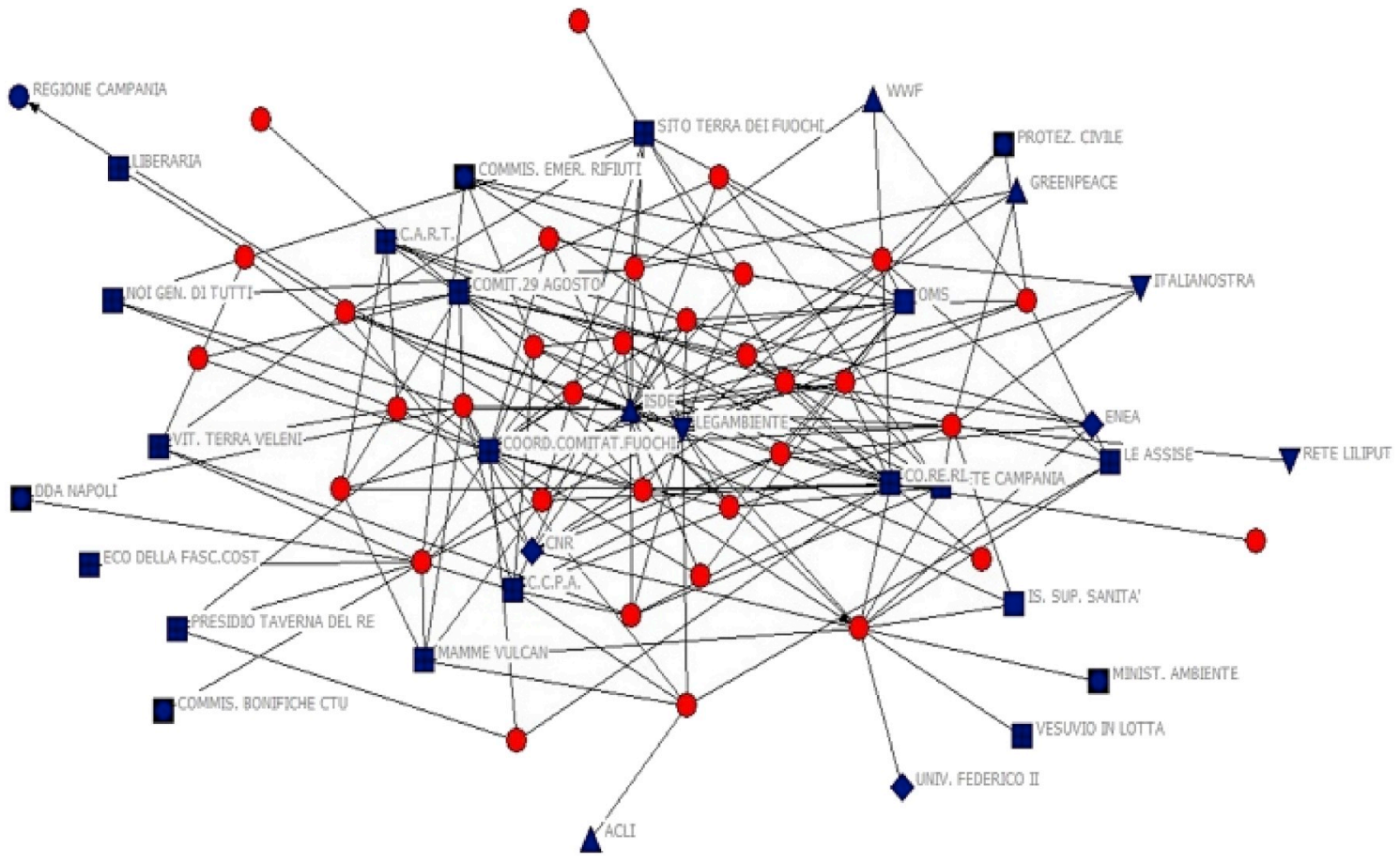

Fig. 9. Affiliation knowledge network 2008-2014. 
Table 3

Affiliation Information and Knowledge Networks: Key indicators.

\begin{tabular}{lllllll}
\hline \multirow{2}{*}{ Key indicators } & AINs & & & AKNs \\
\cline { 2 - 3 } \cline { 6 - 6 } & $2004-2008$ & $2008-2014$ & & $2004-2008$ & $2008-2014$ \\
\hline Number of ties & 135 & 592 & & 118 & 396 \\
Density & 0.031 & 0.134 & & 0.027 & 0.090 \\
Inclusiveness (\%) & 67,5 & 100 & & 59,7 & 100 \\
Clustering coefficient & 0.033 & 0.135 & & 0.029 & 0.096 \\
Average degree & 1.038 & 8.836 & & 1.761 & 5.910 \\
\hline
\end{tabular}

technology (D'Alisa et al., 2010). Another example of success comes out of Pianura's struggle, as explained in Section 2, when, in 2008 (just before the turning point), the activists were able to impede the reopening of an old landfill in the city of Naples (De Biase, 2015). A victory that came after other partially successful struggles such as the one in 2005 in Montesarchio, a small town in the province of Benevento (Fig. 1). There, the activists opposed the opening of a landfill in an area between two regional parks and obtained, after several weeks of barricade, the reduction of the planned capacity of the landfill by $40 \%$ (D'Alisa et al., 2010).

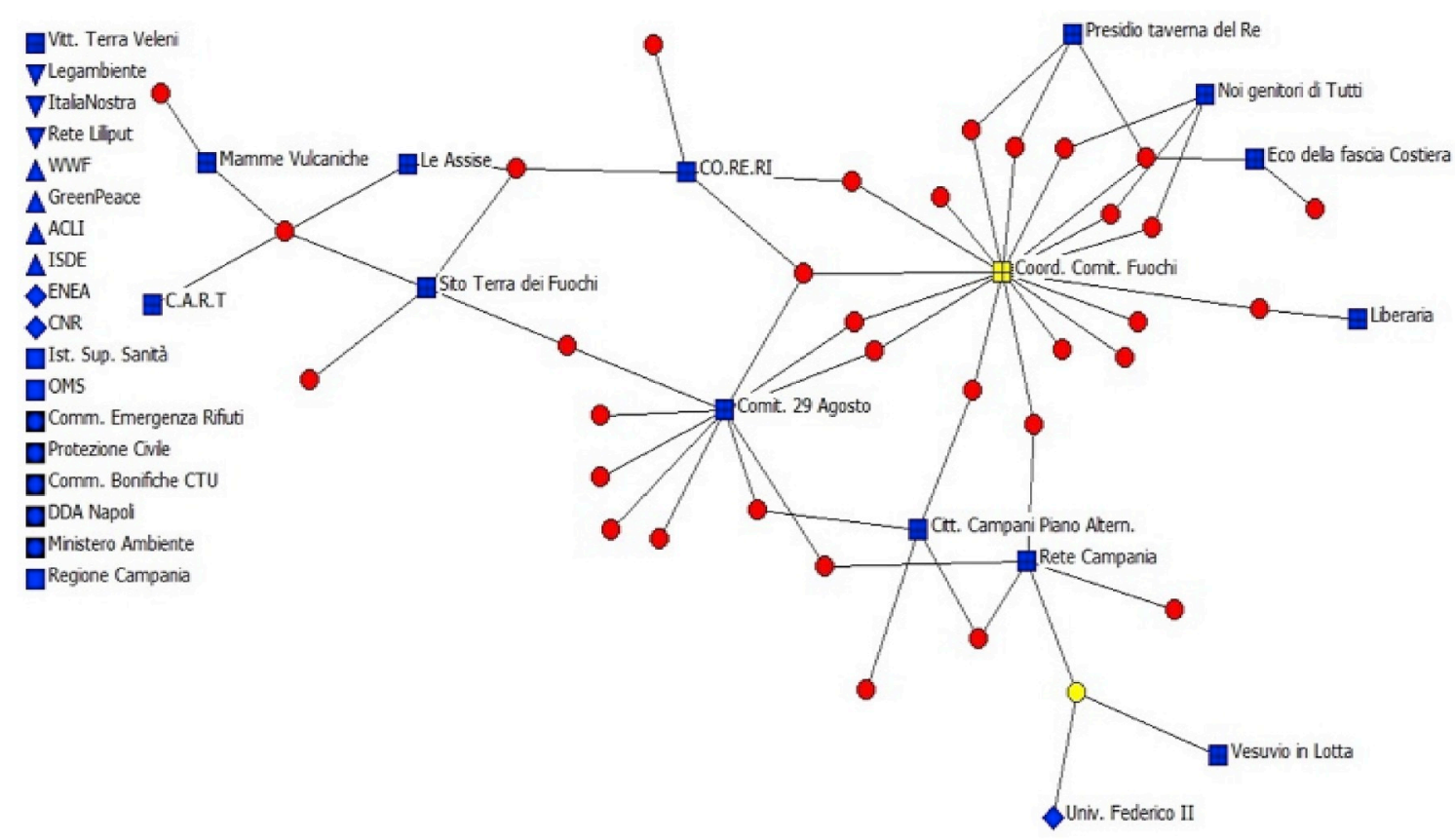

Fig. 10. Affiliation Membership Network 2008-2014 (cut-points analysis).

was mainly focused on alerting the public to the phenomenon of illegal burning of industrial waste in the countryside of Campania. A third cluster, gathered up by "Presidio Taverna Re", ${ }^{10}$ was struggling mainly against the continuous storage of waste blocks in the countryside of the two provinces of Naples and Caserta (see Fig. 1).

The subnetworks exchanged information for undertaking collective actions and resisting collectively the waste plan that the Commissioner to Waste Emergency in Campania (CWEC hereafter) wanted to impose. Before 2008, the organizations of the first cluster (Rete Campania, Comitato 29 Agosto) occupy the center of the AIN together with Legambiente, a national environmental NGO. (Fig. 6). The latter becomes even more central if one looks at the AKN (Fig. 7). CO.RE.RI and Assise also gained centrality in the AKN, which expands further the web of relations of the waste movement in Campania and allows the activists to diversify their sources of knowledge and develop factual alternative waste plans.

The movement won some battles at the scale of specific localities that revealed many management failures of the CWEC. For example, even if the incinerator was finally built, the activists forced the CWEC to impose, in 2006 and 2007, to the consortium of the enterprise that won the tender for several technological improvements to the initially planned incinerator. It was a success if one considers that the consortium would otherwise build the incinerator using the worst available

\footnotetext{
${ }^{10}$ Presidio in English is literally a garrison, Taverna del re (literally the tavern of the king) is the name of the district where the waste blocks to be incinerated were stored while the incinerator was under construction.
}

However, during that period, the structure of the movement was overall weak and not very cohesive; above all, even if the actors exchanged information and knowledge, their frame was still very fragmented. The first and third cluster struggled mainly for a better management of urban waste and for a waste plan that did not prioritize incineration and big landfills. The second cluster focused on the halting of illegal waste trafficking and the remediation of the thousands of contaminated sites in the region. The lack of a unified platform, able to show the common frame that the different struggles shared, allowed simplified representations of this archipelago of organizations to gain support. The opposition to the incineration and to the enlargement of old landfills or the opening of new ones were the most visible activities of the movements. It was therefore easy to depict them as anti-system trouble-makers, as citizens affected by the NIMBY syndrome, or as uncivil citizens unable to sort their own urban waste (Petrillo, 2009, pp. 17-71), and hence ready to be manipulated by local politicians (Pasotti, 2010) or favor camorra interests (Fisher, 2007; The Economist, 2008). Before the turning point, public authorities were able to impose their scale of meaning (Towers, 2000); Campania activists were represented as uncivil people ready to go to any length in order to defend their own backyard.

The structural and cultural violence (Navas et al., 2018) and the unjust misrecognition of people and place (Walker 2010), co-produced by these mainstream frames, sullied the reputation of the waste-related Campania activists. After the violent riots in Pianura shocked the public, it was easy for the members of the national government to impose repressive measures and further criminalize the activists. Among the arrested were a councilor of the municipality of 


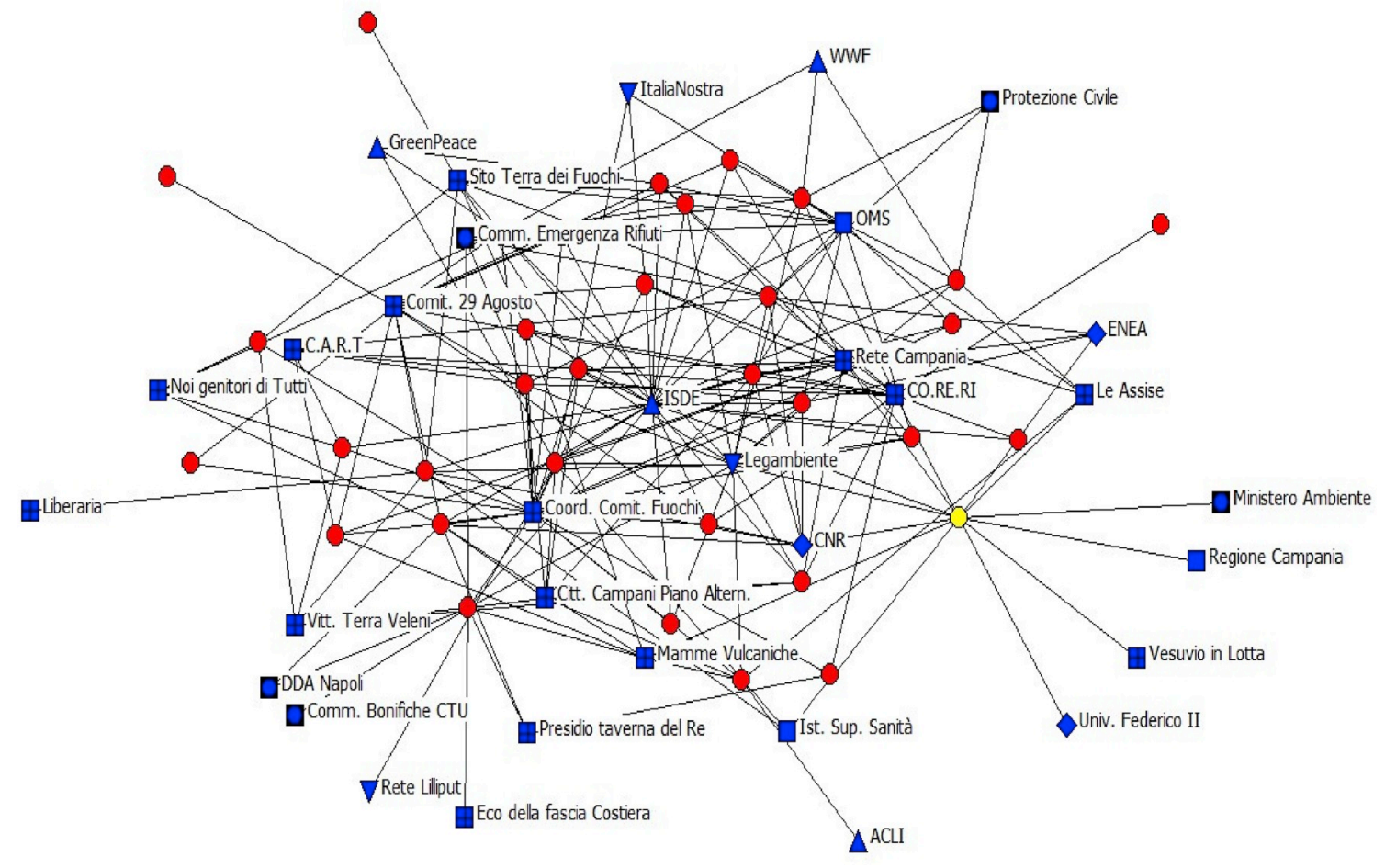

Fig. 11. Affiliation Knowledge Network 2008-2014 (cut-points analysis).

Naples, convicted to eight years of jail in 2014 (La Repubblica, 2014) and an assessor of the municipal government of Naples, who committed suicide days after being accused (Corriere della Sera, 2008).

In 2008, the Prime Minister (PM) convinced all his political opponents that the waste crisis was over. He helped inaugurate the eventually operative incinerator; he convened a series of Council of Ministers' meetings in Naples with the waste crisis being the first item of order. Finally, he issued Decree 90/2008, giving a new turn to the scale of regulation (and oppression) and creating new scale constraints to activists (Jonas, 1994; Towers, 2000). With Decree 90, the constitutional right to demonstrate became a penal felony, and the structural violence against environmental activists became socially and psychologically unbearable. A waste trafficker that disposed or burned waste illegally risked a simple fine if caught, while a citizen demonstrating in the vicinity of an incinerator or a landfill risked imprisonment. Furthermore, Decree 90 issued the opening of 10 new landfills, the building of 4 new incinerators in Campania, and the ordering of the national military to monitor waste facilities now defined as areas of national strategic interest.

Most citizens consented to these repressive measures (D'Alisa \& Armiero, 2013). This popular support bolstered the national government's criminalization complicating further the lives of the activists. They continued to oppose the implementation of Decree 90, as evidenced by the resistance against the landfill of Chiaiano (a district of Naples); there, the grassroots movement remained alive after the opening of the landfill and evolved into a movement that promoted commons and cultivated land seize from the camorra (Armiero \& Sgueglia, 2019). However, in the aftermath of the approval of the Decree 90, different groups split into localized subnetworks and had difficulty gaining the consent of people not directly affected. No new opinion leaders emerged to coalesce the diverse organizations into a unique political platform.

As our results highlight, almost two years after the government began to militarize waste management, new core activists joined the struggle. Most policymakers were convinced that the waste struggles were past, and public opinion concurred. Waste management had been normalized. None predicted the following two phenomena. On one hand, the activists who were part of the movement prior to 2008 promoted the exchange of information and co-production of knowledge, between citizens and scientists, to raise an "expert community" (D'Alisa $\&$ Kallis, 2014) capable of collectively dealing with complex problems of waste plans, contamination and associated health risks (Armiero \& Sgueglia, 2019). On the other hand, new actors were entering the waste conflict; these were affected by the slow violence of contamination. Campania was experiencing an extraordinary increase in cancer morbidity and mortality. Without positing a causal relation between waste-related exposure and the increase of cancer in Campania, which several epidemiological studies have evidenced (Martuzzi et al., 2008; Pirastu et al., 2010), it is worth noting that our results, achieved with the attribute analysis of our networks, show that, after the turning point, most activists that occupy a central role in the movement (Fig. 4) have been affected by a serious disease, or a close relative was ill or dead because of cancer. In other words, illness drove activism after 2008.

Health issues revived waste-related EJ in Campania. A new counter frame emerged; the slow violence of contamination infiltrated the scale of regulation and meaning imposed by public authorities, disarticulating their strategy of violence and criminalization. The scalar framing of health emerged, broadening the politics of the contested space (Kurtz, 2002) of waste conflict in Campania. Between the end of 2010 and 2011 more and more mothers, whose children were affected by and/or died of rare types of cancer, gathered around a charismatic priest of a peripheral district in the province of Naples. These new actors gained momentum and captured the interest of the media and politicians. Supported by thousands of signatures they appealed to the President of the Italian Republic to promote epidemiological studies that would explore the possible casual relation between the death of their children and diffuse waste-related contamination. As toxic contamination slowly manifested its violence (Nixon, 2011) as result of a constant accumulation of pollutants in the soil, subsoil, aquifers, air, and in the bodies of the citizens of Campania, activists framed the injustice as "biocide" (Armiero \& Sgueglia, 2019).

In 2013, "stop biocide" became the broad political platform and general frame that fostered a renaissance of the waste-related EJ movement in Campania. The narrative held together the widening of 
unhealthy space, the criticism of urban waste plan failures and the illegal toxic waste trafficking and disposal, and revealed, as the engine of this environmental disaster, an intricate network of interests including legal businesses, public authorities and the camorra (Fiumeinpiena, 2013). The new wave of activism gained strength and culminated in the biggest demonstration in the history of waste movement in Campania; in 2013, more than 100.000 people flooded the streets of Naples Different activists struggling against other environmental injustices arrived from all over Italy to march with Campania citizens to "stop the biocide" (Armiero \& Sgueglia, 2019).

The Campania movement's renewed capacity for organization can be explained by looking at the results we presented in the previous section. The AIN gained in robustness and cohesiveness after 2008 (Fig. 8). All the indicators that measure the structure of the network increase by a factor of three and four; most importantly the average degree of networking, which is a proxy for the frequency the activists of different organizations meet and collaborate to develop strategies and effective actions useful for the EJ movement as whole, increases more than 8 times (See Table 2). More and new organizations gain centrality of the AIN. "Terra dei Veleni", "ISDE", "Coord. Comitato Fuochi"11 enter in the AIN after 2008 and became core organizations of the network whose center held tightly together (Fig. 8). Older organizations such as "Co.Re. Ri", "Comitato 29th Agosto", "Mamme Vulcaniche" come closer to each other and to the center of the AIN (see Figs. 7 and 8).

On the other hand, the movement's capacity to assemble complex and interdisciplinary knowledge about waste planning, contamination and health epidemiology can be explained by looking at the new robust structure that characterized the AKN after 2008 (Fig. 9). The number of organizations from which the activists acquire knowledge increases incredibly (inclusiveness was 100\%), the number of ties, the density, the clustering coefficient increase by a factor of three. For decades Legambiente had been assembling dossiers about the environmental disaster produced by organized crime's exploitation of environmental resources. It was at the center of the co-production of knowledge but did not collaborate very closely with other grassroots organizations (Fig. 8). On the contrary, the new core of the AKN shows organizations working together much more, and this collaboration goes across scales (Fig. 9). The Coord. Comitato Fuochi was an organization that coordinated among different, old and new, organizations that since 2012 had popped up around Campania enriching the political geography of the conflict. After 2008, the center of the AKN is much thicker and more enriched by new international competencies and expertise. ISDE was very peripheral before 2008; after 2008, it became very central. Its member were doctors who could more effectively diffuse knowledge about the health impacts of waste activities and discuss the results of epidemiological studies with laypersons. Members of the CNR (the Italian National Council of Research) also participated actively in the co-production of knowledge. The average degree indicator signals that activists and scientists met much more often to discuss the facts, data and studies about Campania waste crisis. This intense and intricate collaboration transformed the knowledge produced by experts into communal and shared knowledge and created an "expert community" (Armiero \& Sgueglia, 2019; D'Alisa et al., 2010; D'Alisa \& Kallis, 2014). This expert community was not fragile. Indeed, only a single actor appeared to be a cut-point of the AKN. More importantly, if this actor were to exit the network it would cut off organizations that were not producing dossiers, environmental impact analysis and epidemiological studies (as are Legambiente, ISDE, CNR) that were the main source of knowledge for enriching the stop biocide political platform.

In contrast, the AMN appears partly vulnerable where the cut-point is a central event of the network (Fig. 10). The Coord. Comitato Fuochi was extremely important for the endurance of the waste-related movement in Campania (Fig. 10). This is important and interesting at the same time. It is interesting because the Coord. Comitato Fuochi was a recent organization; it did not exist before 2008 (Fig. 5) but was set up in 2012. It is important because the Coord. Comitato Fuochi has efficiently coordinated the activities of the waste-related movement in Campania. It gathered actors from different organizations with diverse political biographies and personal experiences to come together and sustain an effective political platform: stop biocide.

The waste-related EJ movement in Campania achieved important goals between 2012 and 2015. These go well beyond the partial, though important, successes attained before the turning point, such as the technical improvement of the incineration process, the reduction of the landfill volume in Montesarchio, and the block of the opening of Pianura landfill. The resurgence of a popular movement crossing different social, political and economic groups and the massive protests forced the national government: a) to appoint a special commissioner to oppose the expansion of the phenomenon of toxic smoke and fires (Spagnolo, 2012); b) to recognize as a serious crime the illegal burning of waste (Law 6/2014); c) to map contaminated agriculture sites and impede any cultivation there; d) to plan coordinated interventions for land-reclamation across Campania; e) to institutionalize the boundary of the Land of Fires (LoF) and systematize the monitoring and repression of illegal disposal. In 2003, the LoF was a locution used to indicate three municipalities in the province of Naples where the illegal burning and burying of waste were daily activities. Ten years later and because of the strength of the new waste-related movement in Campania the national government made official (Law 6/2004) the existence and extension of the LoF. Today officially just fewer than 90 municipalities are part of LoF. The contested production of the LoF spatiality is a clear example of a scalar framing in motion (Towers, 2000), because the process of illegal disposal and the consequent contamination continuously undoes the scale of regulation and the space that needs to be regulated.

Last but not least, the waste-related EJ movement in Campania accelerated approval of the introduction in the penal code of environmental crimes (D'Alisa et al., 2017). Moreover, the four new incinerators, planned in the infamous Decree 90, were never built.

Many scholars have demonstrated that through the process of reterritorialization and "commoning," waste-related activists have promoted social cooperatives and ecologically sound production on land seized from camorra families (Armiero \& Sgueglia, 2019; Caggiano \& Rosa, 2015; De Rosa, 2018). Our attribute analysis related to lifestyle shows (Fig. 4) that the movement's core activists claim a rather healthy diet, to smoke and drink little, to practice environmentally sound activities (biking, sorting waste, saving important resources, volunteering in environmental organizations, etc.). Our results reinforce the EJ scholar's thesis that environmental defenders are a force of just and ecological transitions (Scheidel et al., 2018; Temper et al., 2018).

However, our main aim in developing this study was not to support this thesis, it was to contribute to understanding the change in the structural properties of the waste movement networks in Campania and how it was able to regain strength after a process of criminalization and repression. We have shown that Decree 90/2008 and the measures it contained inhibited the movement and dissuaded activists from gathering and struggling together; but this was true only for a few years, from 2008 to 2011. When new actors and organizations became central to the waste movement network, activists strengthened its cohesiveness and unified under a platform articulated around health ${ }^{12}$ problems caused by mismanagement and illegal burning and burying of waste.

\footnotetext{
11 The extensive name in English of: a) "Terra dei Veleni" is "Committee Land of Fire and Poisons"; b) "ISDE" is International Society of Doctors for Environment; c) Coord. Comitato Fuochi is "Coordination Fire Committee"; 4) "Mamme Vulcaniche" is "“Volcanic Mothers".
} 12 The national authorities have accepted also this narrative. Indeed, the
apparatus that care about the phenomenon of the Land of Fire is the Minister of
Health (see: http://www.salute.gov.it/portale/news/p3_2_3_1_1.jsp?lingua
$=$ italiano\&menu=dossier\&p=dadossier\&id=36). 
Our results support the thesis of those few scholars that have applied SNA to study environmental struggles (Özkaynak, Rodríguez-Labajos, Aydin, Yanez, \& Garibay, 2015, p. 96). These scholars show that successful struggle depends on three factors: a) the number of civil society organizations participating in conflicts, whose number after 2008 increased incredibly in Campania; b) a tight interconnection between the core and the peripheral organizations of the network, something that occurred after 2008 in Campania. All indicators of cohesiveness affiliation networks we have studied increased on average of a factor of three and half; c) the capacity to develop relations at multiple scales with national and international actors, something visible above all in the AKN we have analyzed for the Campania case. What we also explain with this study relates to how an EJ movement can achieve important goals after a period of criminalization and violence. EJ literature shows that these socio-political processes often cause environmental conflicts' failures (Del Bene et al., 2018; Mingorría, 2018; Özkaynak et al., 2015, p. 96). Campania's activists suffered structural, cultural and slow violence, following the multidimensional categorization of Navas et al. (2018); however, our results clearly show, by analyzing the structural characteristics of movement networks before and after a turning point, that the waste-related movement in Campania, after a moment of loss that compromised for some years its organizational capacity, was able to increase its cohesiveness and improve the efficacy of its life struggle.

Political geographers have suggested that for a successful environmental movements activists should be able to adjust different framing to the different contested scale of the struggle (Kurtz, 2002; Towers, 2000). Our results show that this would not be sufficient, because if the activists are not able to articulate together the multiple contested frames they produced for the several geographies of injustice at play in the conflict in a unique political platform (as it was for "stop biocide"), their struggle is likely to prove ineffective because the environmental movement would remain an archipelago of sub-clustered networks, as it was for the waste-related movement in Campania before 2008.

\section{Conclusions}

Campania's waste-related environmental conflict has been extensively studied. The most recent works show that waste activists are important forces of socially just and ecologically sound transitions, in line with recent interest of EJ scholars. However, this extensive scholarship never investigated the structural properties and the vulnerabilities of the waste movement in Campania. We fill this gap. We have developed an SNA on the waste-related EJ movement in Campania, and offered two representations of its relational networks. We have studied it before and after a turning point (i.e., the year 2008) when government criminalization of activists and militarization of waste management peaked.

We have analyzed three networks: the Affiliation Membership Network, the Affiliation Information Network and the Affiliation Knowledge Network. Each improved in robustness and cohesiveness after 2008. The waste-related movement in Campania passed from being an archipelago of isolated clusters with multiple but fragmented frames (before the 2008), to an interconnected network with components held tightly together. After 2008, this network was able to generate not only an hegemonic scalar framing around the health consequences of the mismanagement and the illegal burying and burning of waste, but it was also able to re-articulate the multiple layers of unjust spatiality, both between and across scales. The revived strength of the waste movement forced the national government to implement environmental policies, such as the recognition of waste burning as a serious crime, and it has had positive consequences for EJ movements well beyond the Campania region.

With our results, we conclude that the Affiliation Knowledge Network of Campania's movement was not particularly vulnerable. The grassroots ways by which activists engaged gave rise to an efficient network architecture for the diffusion of knowledge. Indeed, the AKN's unique cut-point was a peripheral actor connected with organizations not central in the production of data and analysis related to health (core argument of the movement after the turning point). The network was both flexible and non-stratified; there were several alternative interaction pathways among actors that engaged at multiple levels with national and international organizations which provided leverage for further local mobilizations and well substantiated claims and proposals.

A certain degree of fragility (read: vulnerability) characterized the Affiliation Membership Network. One of the new organizations occupying a central role in the network after 2008 was a cut-point. This implies that if for some internal (e.g., irresolvable conflict among activists) or external reason (e.g., declared unlawful by decree) the organization were to dissolve, there would be serious consequences to the structure of the network that would jeopardize the patrimony of competencies of the community's mobilization capacity.

Our results contribute to understanding the inner dynamic of an environmental justice movement and to explain its capacity to rearticulate its organizational and framing capacity when objectives and gains are reversed through the processes of criminalization and repression. EJ scholarship shows that structural and cultural violence cause environmental conflict failure. This is why we maintain that it is important to study empirically the structural evolution of an environmental conflict across time. Together with cross-sectional studies that use SNA to look at the success of environmental conflicts, it is necessary to develop longitudinal studies, such as the one we have done, to understand how different cycles of mobilization can achieve important goals even after periods of criminalization and militarization, and to assess how EJ actors can map out a new counter frame and overcome existing scales of regulation, oppression and meaning that constrain them. Violence explains why many environmental conflicts fail. But violence is not the dead end of environmental conflicts. It is important to produce knowledge to understand how socio-environmental movements overcome periods of heavy repression. It is useful for each socioenvironmental activist and engaged scholar to keep hoping when everything seems lost.

\section{Declarations of competing interest}

None.

\section{Acknowledgements}

This article was developed in the context of EFFACE Project (European Union Action to Fight Environmental Crimes). EFFACE has received funding from the European Union's Seventh Framework Programme for research, technological development and demonstration under G.A. no 320276.

\section{Appendix A. Supplementary data}

Supplementary data related to this article can be found at https ://doi.org/10.1016/j.polgeo.2019.102114.

\section{References}

Abbot, A. (2014). A toxic legacy. Nature, 508(431). https://doi.org/10.1038/508431a. Ackland, R., \& O'Neil, M. (2011). Online collective identity: The case of the environmental movement. Social Networks, 33(3), 177-190. https://doi.org/ 10.1016/j.socnet.2011.03.001.

Agyeman, J., \& Evans, B. (2004). 'Just sustainability': The emerging discourse of environmental justice in Britain? Geographical Journal, 170(2), 155-164.

Armiero, M., \& D'Alisa, G. (2012). Rights of resistance: The garbage struggles for environmental justice in Campania, Italy. Capitalism Nature Socialism, 23(4), 52-68. https://doi.org/10.1080/10455752.2012.724200.

Armiero, M., \& D'Alisa, G. (2013). Voices, clues, numbers: Roaming among waste in Campania. Capitalism Nature Socialism, 24(4), 7-16. https://doi.org/10.1080/ 10455752.2013.851262. 
Armiero, M., \& Sgueglia, L. (2019). Wasted spaces, resisting people: The politics of waste in Naples, Italy. Revista Tempo e Argumento, 11(26), 135-156. https://doi.org/ 10.5965/2175180311262019135.

ARPAC. (2005). Piano regionale di bonifica dei siti inquinati della regione Campania. Napoli. Retrieved November 25, 2018, from http://www.regione.campania.it/assets/do cuments/piano-bonifica-44aucy7c.pdf.

Aydin, C. I., Ozkaynak, B., Rodríguez-Labajos, B., \& Yenilmez, T. (2017). Network effects in environmental justice struggles: An investigation of conflicts between mining companies and civil society organizations from a network perspective. PLoS One, 12 (7). https://doi.org/10.1371/journal.pone.0180494. e0180494.

Bosi, L., Giugni, M., \& Uba, K. (2016). The consequences of social movements. Cambridge University Press.

Bullard, R. D., \& Johnson, G. S. (2000). Environmentalism and public policy: Environmental justice: Grassroots activism and its impact on public policy decision making. Journal of Social Issues, 56(3), 555-578.

Butts, C. T. (2008). Social network analysis: A methodological introduction. Asian Journal of Social Psychology, 11(1), 13-41.

Caggiano, M., \& De Rosa, S. P. (2015). Social economy as antidote to criminal economy: How social cooperation is reclaiming commons in the context of Campania's environmental conflicts. Partecipazione e Conflitto, 8(2), 530-554.

Capocaccia, R., Comba, P., Conti, S., \& De Angelis, R. (2012). Situazione epidemiologica della regione Campania ed in particolare delle province di Caserta e Napoli (città esclusa), con riferimento all'incidenza della mortalità per malattie oncologiche. Relazione Finale Del Gruppo Di Lavoro Ex DM, 24(07). Retrieved November 25, 2018, from www.salu te.gov.it/imgs/c 17 pubblicazioni 1883 allegato.pdf.

Conde, M., \& Walter, M. (2014). Commodity frontiers. Degrowth. A Vocabulary for a New Era.

Corriere della Sera. (2008, November 29). Si toglie la vita l'ex assessore coinvolto nell'inchiesta per gli scontri a Pianura. Retrieved November 25, 2018, from https: //www.corriere.it/cronache/08 novembre 29/assessore tenta suicidio ca5f8cfo-b e0b-11dd-99ec-00144f02aabc.shtml.

De Biase, M. (2015). Fires of Pianura: The antidump struggle in the western outskirt of naples. Capitalism Nature Socialism, 26(1), 39-58. https://doi.org/10.1080/ 10455752.2014 .996580$.

De Nardo, J. (2014). Power in numbers: The political strategy of protest and rebellion (Vol. 41). Princeton University Press.

De Rosa, S. P. (2018). A political geography of 'waste wars' in Campania (Italy): Competing territorialisations and socio-environmental conflicts. Political Geography, 67, 46-55. https://doi.org/10.1016/j.polgeo.2018.09.009.

Del Bene, D., Scheidel, A., \& Temper, L. (2018). More dams, more violence? A global analysis on resistances and repression around conflictive dams through co-produced knowledge. Sustainability Science, 13(3), 617-633. https://doi.org/10.1007/s11625018-0558-1.

Demaria, F., \& Schindler, S. (2016). Contesting urban metabolism: Struggles over wasteto-energy in Delhi, India. Antipode, 48(2), 293-313. https://doi.org/10.1111/ anti.12191.

D’Alisa, G., \& Armiero, M. (2011). La ciudad de los residuos: Justicia ambiental e incertidumbre en la crisis de los residuos en Campania (Italia). Ecología Política, 41, 97-105.

D'Alisa, G., \& Armiero, M. (2013). What happened to the trash? Political miracles and real statistics in an emergency regime. Capitalism Nature Socialism, 24(4), 29-45. https://doi.org/10.1080/10455752.2013.849747.

D’Alisa, G., Armiero, M., \& De Rosa, S. P. (2014). Political ecology: Rethink Campania's toxic-waste scandal. Nature, 509(7501), 427. https://doi.org/10.1038/509427d.

D’Alisa, G., Burgalassi, D., Healy, H., \& Walter, M. (2010). Conflict in Campania: Waste emergency or crisis of democracy. Ecological Economics, 70(2), 239-249. https://doi. org/10.1016/j.ecolecon.2010.06.021.

D'Alisa, Giacomo, \& Demaria, F. (2013). Alle frontiere del capitale. Zapruder, 30, 38-50.

D'Alisa, G., Germani, A. R., Falcone, P. M., \& Morone, P. (2017). Political ecology of health in the land of fires: A hotspot of environmental crimes in the South of Italy. Journal of Political Ecology, 24(1), 59-86.

D’Alisa, G., \& Kallis, G. (2014). Post-normal science. In G. D. 'Alisa, F. Demaria, \& G. Kallis (Eds.), Degrowth: A vocabulary for a new era. Routledge.

D'Alisa, G., Di Nola, M. F., \& Giampietro, M. (2012). A multi-scale analysis of urban waste metabolism: Density of waste disposed in Campania. Journal of Cleaner Production, 35, 59-70. https://doi.org/10.1016/j.jclepro.2012.05.017.

de Falco, G. (2014). Traffico illecito dei rifiuti: Un approaccio giudiziario. Gazzetta Ambiente, 4, 71-75.

Fazzo, L., Belli, S., Minichilli, F., Mitis, F., Santoro, M., Martina, L., ... Bianchi, F. (2008). Cluster analysis of mortality and malformations in the provinces of Naples and Caserta (Campania region). Annali Dell'Istituto Superiore Di Sanita, 44(1), 99-111.

Fisher, I. (2007). In mire of politics and the mafia, garbage reigns. The New York Times. Retrieved August 25, 2019 http://www.nytimes.com/2007/05/31/world/europe/ 31naples.html? pagewanted $=1 \& \_r=1$.

Fiumeinpiena. (2013). Come fermare il biocidio in dieci punti. Piattaforma politica $\mid$ A Sud ONLUS. Retrieved August 25, 2019, from http://asud.net/come-fermare-il-biocidio -in-dieci-punti-la-piattaforma-di-fiumeinpiena/.

Gleeson, B., \& Low, N. (2002). Justice, society and nature: An exploration of political ecology. Routledge.

Global Witness. (2016). On dangerous grounds. Report June 20, 2016. Retrieved August 25, 2019, from https://www.globalwitness.org/en/campaigns/environmental-act ivists/dangerous-ground/.

Hill, D. (2016). Never seen it so bad': Violence and impunity in Brazil's Amazon. The Guardian. Retrieved August 25, 2019, from https://www.theguardian.com/environ ment/andes-to-the-amazon/2016/feb/16/neverseen-it-so-bad-violence-and-impunit y-in-brazils-amazon.
Huh, M.-H., \& Lee, Y.-G. (2011). Monte-carlo methods for social network analysis. The Korean journal of applied statistics, 24(2), 401-409.

Iacuelli, A. (2008). Le vie infinite dei rifiuti. Il sistema campano (Rinascita edizioni).

Iannello, C. (2007). L'emergenza rifiuti in Campania: i paradossi delle gestioni commissariali (Vol. 2). Rassegna Di Diritto Pubblico Europeo.

Iengo, I., \& Armiero, M. (2017). The politicization of ill bodies in Campania, Italy. Journal of Political Ecology, 24(1), 44. https://doi.org/10.2458/v24i1.20781.

ISTAT. (2016). Indicatori Demografici - Stime per l'anno 2015 Accessed on 22 November, 2018, from http://www.istat.it.

Jonas, A. E. G. (1994). The scale politics of spaliality. London, England: SAGE Publications Sage UK.

Kurtz, H. E. (2002). The politics of environmental justice as the politics of scale: St. James Parish, Louisiana, and the Shintech siting controversy. Geographies of Power: Placing Scale, 249-273.

La Repubblica. (2014, May 17). Rifiuti, sentenza sulla rivolta di Pianura: 8 anni a Nonno. Condannati anche due ultrà del Napoli, 17 maggio. Retrieved on 22 November, 2018 from https://napoli.repubblica.it/cronaca/2014/05/07/news/rivolta_di_pianura _nonno_condannato_a_8_anni_e_mezzo-85505341/.

Legambiente. (2003). Rapporto ecomafia. Retrieved on 17 October 2018, from http://www.amblav.it/Download/Legambiente-Rapporto_Ecomafia2003.pdf.

Martinez-Alier, J. (2002). The environmentalism of the poor: A study of ecological conflicts and valuation. Edward Elgar Publishing.

Martínez-Alier, J., \& O'Connor, M. (1996). Ecological and economic distribution conflicts. In R. Costanza, O. Segura, \& J. Martinez-Alier (Eds.), Washington: Getting down to earth (pp. 153-183). Practical Applications of Ecological Economics Island Press.

Martuzzi, M., Bianchi, F., Comba, P., Fazzo, L., Minichilli, F., \& Mitis, F. (2008). Trattamento dei rifiuti in Campania. Studio di correlazione tra rischio ambientale da rifiuti, mortalità e malformazioni congenite. Report ordered by the Italian Department of Civil Protection. Retrieved 17 October 2018, from https://www.protezionecivile. gov.it.

Mingorría, S. (2018). Violence and visibility in oil palm and sugarcane conflicts: The case of Polochic Valley, Guatemala. Journal of Peasant Studies, 45(7), 1314-1340.

Moore, J. W. (2000). Sugar and the expansion of the early modern world-economy: Commodity frontiers, ecological transformation, and industrialization. Review (Fernand Braudel Center).

Morone, Piergiuseppe, Falcone, P. M., \& Tartiu, V. E. (2019). Food waste valorisation: Assessing the effectiveness of collaborative research networks through the lenses of a COST action. Journal of Cleaner Production, 238(117868). https://doi.org/10.1016/j. jclepro.2019.117868.

Morone, P., Tartiu, V. E., \& Falcone, P. (2015). Assessing the potential of biowaste for bioplastics production through social network analysis. Journal of Cleaner Production, 90, 43-54. https://doi.org/10.1016/j.jclepro.2014.11.069.

Navas, G., Mingorria, S., \& Aguilar-González, B. (2018). Violence in environmental conflicts: The need for a multidimensional approach. Sustainability Science, 13(3), 649-660. https://doi.org/10.1007/s11625-018-0551-8.

Nixon, R. (2011). Slow violence and the environmentalism of the poor. Harvard University Press.

Nugroho, Y., \& Saritas, O. (2009). Incorporating network perspectives in foresight: A methodological proposal. Foresight, 11(6), 21-41.

Ozkan-Canbolat, E., \& Beraha, A. (2016). Configuration and innovation related network topology. Journal of Innovation \& Knowledge, 1(2), 91-98. https://doi.org/10.1016/j. jik.2016.01.013.

Özkaynak, B., Rodríguez-Labajos, B., Aydın, C.İ., Yanez, I., \& Garibay, C. (2015). EJOLT Report. Towards environmental justice success in mining conflicts: An empirical investigation, 14.

Pasotti, E. (2010). Sorting through the trash: The waste management crisis in Southern Italy. South European Society \& Politics, 15(2), 289-307.

Peet, R., Robbins, P., \& Watts, M. (2010). Global political ecology. Routledge.

Pellow, D. (2004). The politics of illegal dumping: An environmental justice framework. Qualitative Sociology, 27(4), 511-525. https://doi.org/10.1023/B:QUAS.00000 49245.55208.4b.

Pellow, D. (2007). Resisting global toxics: Transnational movements for environmental justice. mit Press.

Pellow, \& Naguib, David (2002). Garbage wars: The struggle for environmental justice in Chicago.

Pellow, David N., Weinberg, A., \& Schnaiberg, A. (2001). The environmental justice movement: Equitable allocation of the costs and benefits of environmental management outcomes. Social Justice Research, 14(4), 423-439.

Peluso, N. L., \& Watts, M. (2001). Violent environments. Cornell University Press.

Petrillo, A. (2009). Le urla e il silenzio. Depoliticizzazione dei conflitti e parresia nella Campania tardo-liberale. Biopolitica Di Un Rifiuto. Le Rivolte Anti-Discarica a Napoli e in Campania.

Pirastu, R., Ancona, C., Iavarone, I., Mitis, F., Zona, A., \& Comba, P. (2010). Studio epidemiologico Nazionale dei Territori e degli Insediamenti Esposti a Rischio da Inquinamento-SENTIERI Valutazione dell'evidenza epidemiologica [SENTIERI project. Epidemiological study in contaminated sites in Italy: Evaluation of the epidemiologic. Epidemiologia e Prevenzione, 34, 5-6.

Poon, J. P. H., Tan, G. K. S., \& Hamilton, T. (2019). Social power, offshore financial intermediaries and a network regulatory imaginary. Political Geography, 68, 55-65. https://doi.org/10.1016/j.polgeo.2018.11.005.

Radil, S. M., \& Walther, O. J. (2018). Social networks and geography: A view from the periphery. ArXiv Preprint ArXiv:1805.04510.

Saviano, R. (2006). Gomorra. Edizioni Mondadori. 
Scheidel, A., Temper, L., Demaria, F., \& Martínez-Alier, J. (2018). Ecological distribution conflicts as forces for sustainability: An overview and conceptual framework. Sustainability Science, 13(3), 585-598. https://doi.org/10.1007/s11625-017-0519-0.

Schlosberg, D. (2013). Theorising environmental justice: The expanding sphere of a discourse. Environmental Politics, 22(1), 37-55. https://doi.org/10.1080/ 09644016.2013 .755387$.

Schlosberg, M. D. (2014). Networks and mobile arrangements: Organisational innovation in the US environmental justice movement. In Environmental movements (pp. 128-154). Routledge.

Smarrazzo, D. (1999). Documenti e studi per una definizione dell'area metropolitana di Napoli. In A. Dal Piaz, \& F. Forte (Eds.), Pianificazione Urbanistica Ed Ambiente, Maggioli, Rimini (a Cura Di).

Sollund, R., Stefes, C. H., \& Germani, A. R. (2016). Fighting environmental crime in Europe and beyond: The role of the EU and its member states. Palgrave Macmillan Publishers.

Spagnolo, V. (2012). Lotta ai roghi tossici: c'è un commissario. Retrieved August 25, 2019, from https://www.avvenire.it/attualita/pagine/roghi-tossici-la-mossa-del-commiss ario.

Swyngedouw, E., \& Heynen, N. C. (2003). Urban political ecology, justice and the politics of scale. Antipode, 35(5), 898-918. https://doi.org/10.1111/j.14678330.2003.00364.x.

Temper, L., Demaria, F., Scheidel, A., Del Bene, D., \& Martinez-Alier, J. (2018). The global environmental justice atlas (EJAtlas): Ecological distribution conflicts as forces for sustainability. Sustainability Science, 13(3), 573-584.

The Economist. (2008). Rubbish in Naples. See it and die. The real crisis in Naples is about governance as much as Rubbish. The Economist. Retrieved August 25, 2019, from http://www.economist.com/node/0499135.
Towers, G. (2000). Applying the political geography of scale: Grassroots strategies and environmental justice. The Professional Geographer, 52(1), 23-36. https://doi.org/ 10.1111/0033-0124.00202.

Vagliasindi, G. M., Lucifora, A., \& Bianco, F. (2015). Fighting environmental crime in Italy: A country report. Study in the framework of the EFFACE research project. Catania: University of Catania. Retrieved August 25, 2019 from https://efface.eu/sites/def ault/files/EFFACE_Fighting\%20Environmental\%20Crime\%20in\%20Italy.pdf.

Velicu, I. (2019). De-growing environmental justice: Reflections from anti-mining movements in Eastern Europe. Ecological Economics, 159, 271-278. https://doi.org/ 10.1016/j.ecolecon.2019.01.021.

Velicu, I., \& Kaika, M. (2017). Undoing environmental justice: Re-imagining equality in the Rosia Montana anti-mining movement. Geoforum, 84, 305-315. https://doi.org/ 10.1016/j.geoforum.2015.10.012.

Walker, G. (2009). Beyond distribution and proximity: Exploring the multiple spatialities of environmental justice. Antipode, 41(4), 614-636.

Walker, G. (2010). Environmental justice, impact assessment and the politics of knowledge: The implications of assessing the social distribution of environmental outcomes. Environmental impact assessment review, 30(5), 312-318.

Wanke, P., \& Falcão, B. B. (2017). Cargo allocation in Brazilian ports: An analysis through fuzzy logic and social networks. Journal of Transport Geography, 60, 33-46. https://doi.org/10.1016/j.jtrangeo.2017.02.006.

Wasserman, S., \& Faust, K. (1994). Social network analysis: Methods and applications (Vol. 8). Cambridge university press.

Weber, G., Calaf-Forn, M., Puig-Ventosa, I., Cabras, I., \& D'Alisa, G. (2018). The role of environmental organisations on urban transformation: The case of waste management in Esporles (Mallorca). Journal of Cleaner Production, 195, 1546-1557. https://doi.org/10.1016/j.jclepro.2017.08.241. 